The University of Maine

DigitalCommons@UMaine

Maine History Documents

Special Collections

1929

\title{
The Scenery of Mt. Desert Island: its Origin and Development
}

Erwin J. Raisz

Follow this and additional works at: https://digitalcommons.library.umaine.edu/mainehistory

Part of the History Commons

\section{Repository Citation}

Raisz, Erwin J., "The Scenery of Mt. Desert Island: its Origin and Development" (1929). Maine History Documents. 93.

https://digitalcommons.library.umaine.edu/mainehistory/93

This Monograph is brought to you for free and open access by DigitalCommons@UMaine. It has been accepted for inclusion in Maine History Documents by an authorized administrator of DigitalCommons@UMaine. For more information, please contact 
ANNALS OF THE NEW YORK ACADEMY OF SCIENCES

Vol. XXXI, Pp. 121-186

Editor, Herbert F. Schwarz

\section{THE SCENERY OF MT. DESERT ISLAND:} ITS ORIGIN AND DEVELOPMENT

BY

ERwin J. Raisz

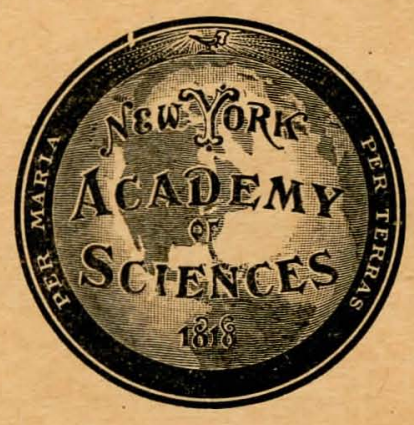

NEW YORK

PUBLISHED BY THE ACADEMY

September 18,1929 


\section{THE NEW YORK ACADEMY OF SCIENCES}

(Lyceum of Natural History, 181\%-18i6)

OfFicers, 1929

President-Charles P. Berikey

Vice-Presidents-J. J. Galloway, G. Kingsley Noble, Frederick W. Hodge

- Corresponding Secretary-Horace W. Stunkard

Recording Secretary-Roy WaLdo Miner

Treasurer-George H. SHeRwood

Librarian-Wildiam K. Gregory

Editor-Herbert F. SohWARz

\section{SECTION OF GEOLOGY}

Chairman-J. J. GaLLowaY

Secretary-H. N. CoRYeLL

$$
\text { SECTION OF BIOLOGY }
$$

Chairman-G. KingsLey Noble

Secretary-Horace W. Stunkard

\section{SECTION OF ANTHROPOLOGY AND PSYCHOLOGY}

Chairman-Frederick W. Hodge

Secretary-Clarence L. HaY

The sessions of the Academy are held on Monday evenings at 8:15 o'clock from October to May, inclusive, at The American Museum of Natural History, 7 \%th Street and Central Park West. 
Dedicated to

George B. Dorr,

lover of Nature, and creator of Acadia National Park. 


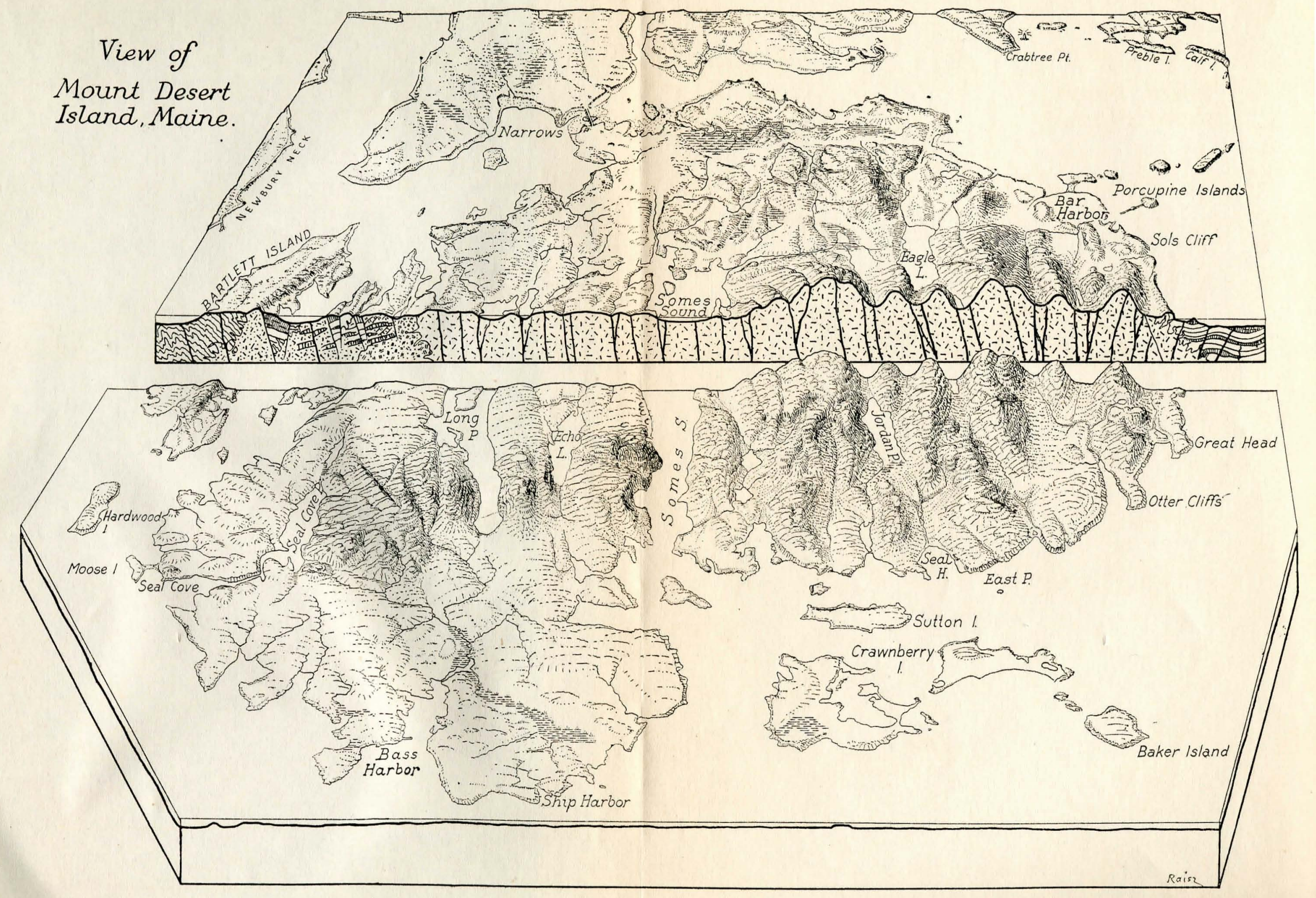


[Annals N. Y. ACad. ScI., Vol. XXXI, pp. 121-186, September 18, 1929$]$

\section{THE SCENERY OF MT. DESERT ISLAND: ITS ORIGIN AND DEVELOPMENT *}

By Erwin J. Raisz

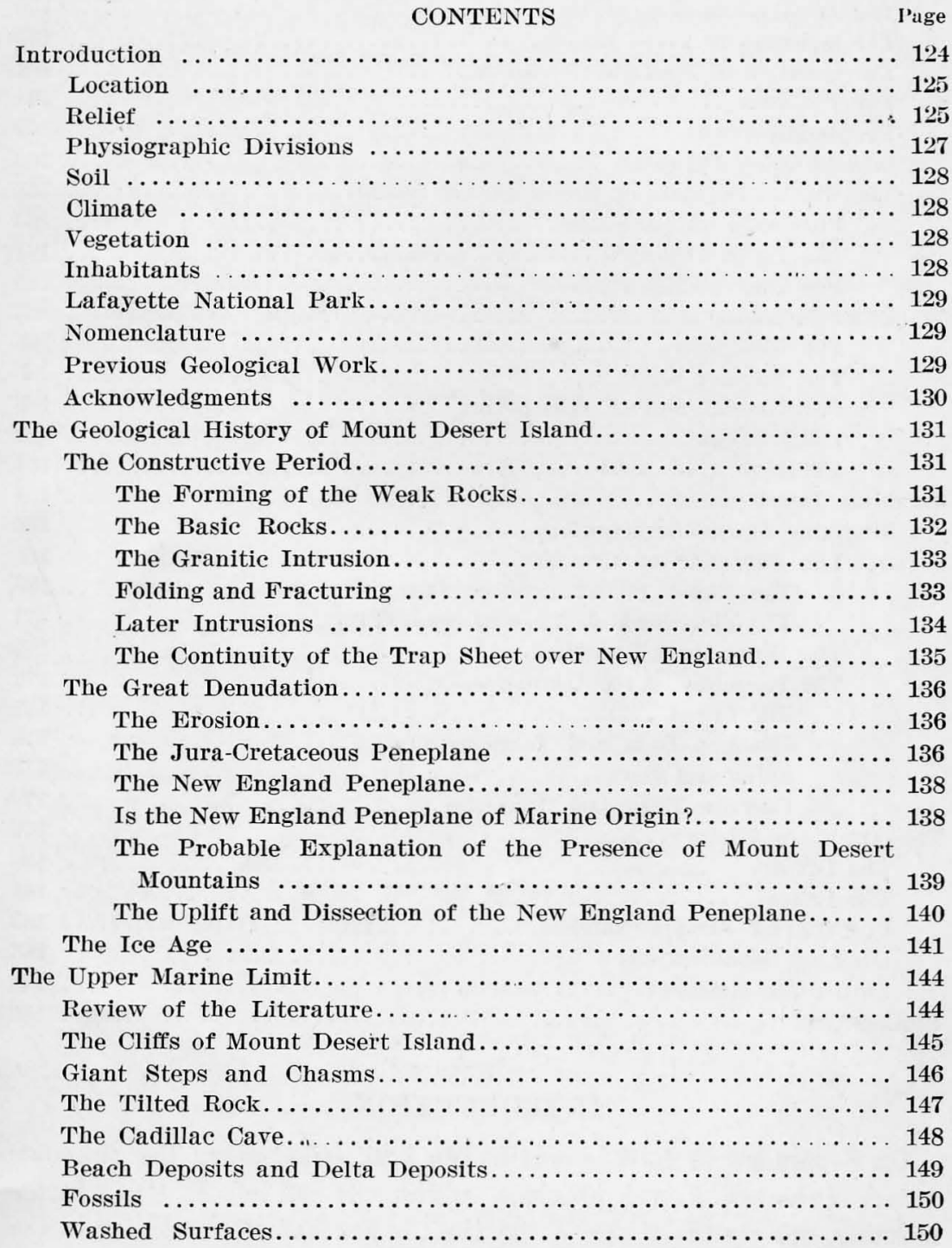

* The publication of this paner has been made possible through a grant from the income of the .Tohn Strong Newberry Fund, supplemented by a generous contribution received through the Department of Geology, Columbia University. 


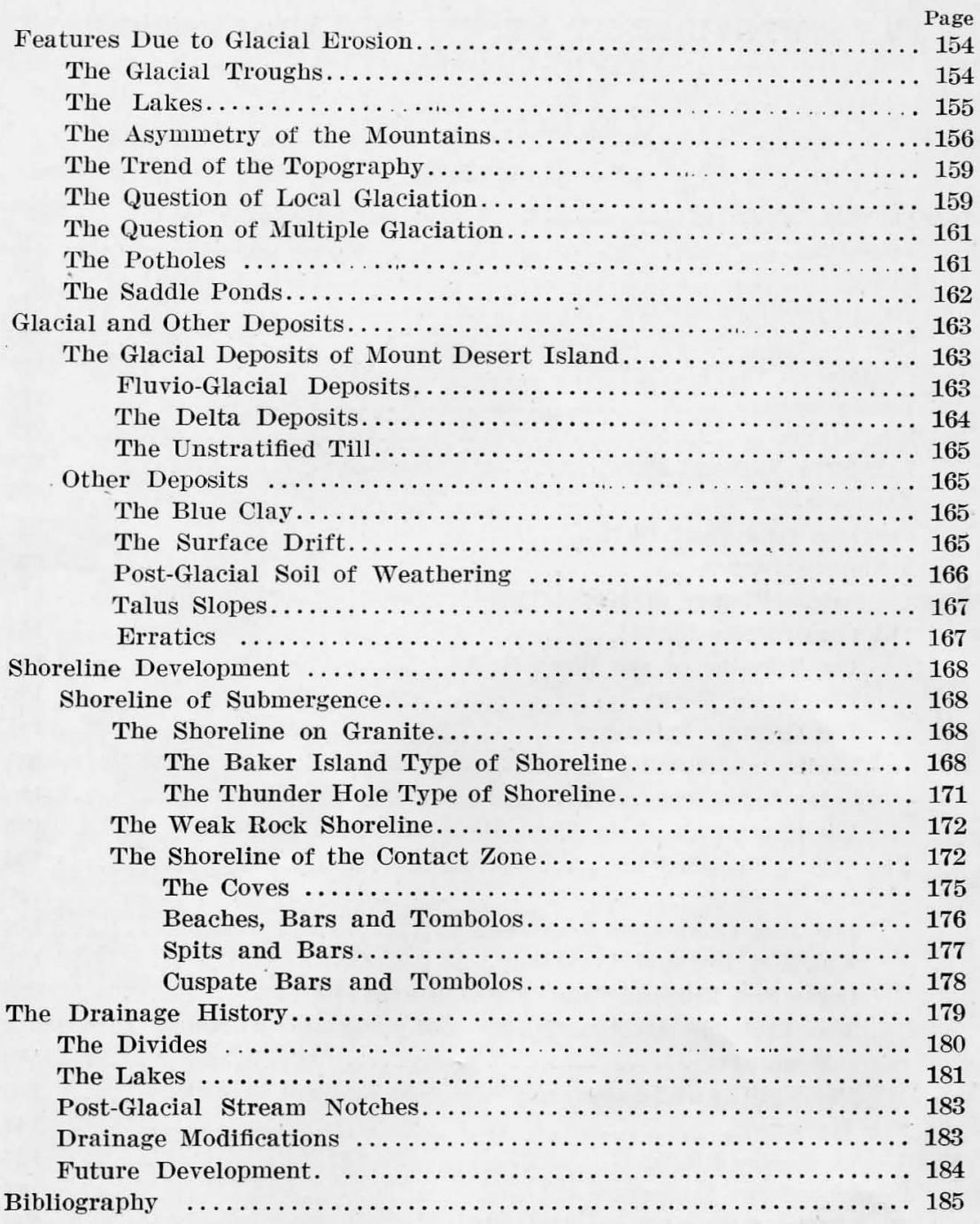

\section{INTRODUCTION}

On September 5, 1604, a small open boat sailed along the unknown waters of the new French province, Acadia. It had left St. Croix in the morning, and on the wings of the fresh breeze had advanced far to the southwest along the coast. There were fourteen men in the boat, and their commander was the famous navigator, Samuel Champlain. 
The coast along which they sailed was a rocky archipelago, with deep bays and peninsulas full of islands and perilous ledges. The land was covered with heavy forest. It was surprisingly low for its rugged character. Nowhere was the general elevation more than a few hundred feet.

At sunset suddenly a bold mountain range appeared in the west, apparently rising directly from the sea. Here the explorers landed. After closer examination on the following days they found that the mountains formed the backbone of an island roughly circular in shape, ten miles across and separated only by a narrow channel from the mainland. The range ". . . is very high and notched in places, so that there is the appearance to one at the sea of seven or eight mountains extending parallel with each other. . . . The summit of them is destitute of trees, as there are only rocks upon them." Thus writes Champlain and accordingly he named the island "Isle des Monts Deserts."

The "Island of the Barren Mountains" proved to be the largest island of the Gulf of Maine (100 square miles) and the loftiest piece of land along the Atlantic coast of the United States (152\%').

\section{LOCATION}

Fig. 1 shows the location of the Island, in the physiographic province known as the "New England Upland." If we take into consideration the part of this province which is submerged under sea level at the present time, Mount Desert Island is nearly in the center of it, midway between the mountains on the Canadian border and the Newfoundland Banks. It is suggested that in order to follow the discussion with full understanding, the reader have before him the Lafayette National Park topographic sheet, published by the United States Geological Survey and bearing on its reverse side an account of the geology of Mount Desert by George M. Wood.

\section{RELIEF}

The Island is composed of a central granitic mass nearly circular in shape and surrounded on all sides with older and weaker rocks.

In physiographic terms the surface of the Island forms parts of the New England peneplane, ${ }^{*}$ and the central mountainous mass is an

* If erosion acts upon a region for a sufficiently long time, it finally wears down the land to an undulating lowland near sea level. Such a lowland was termed by W. M. Davis a "peneplain" (almost a plane), later spelled by Johnson "peneplane." Hills or mountains left standing above the peneplane are called "monadnocks" after Mount Monadnock in New Hampshire. 


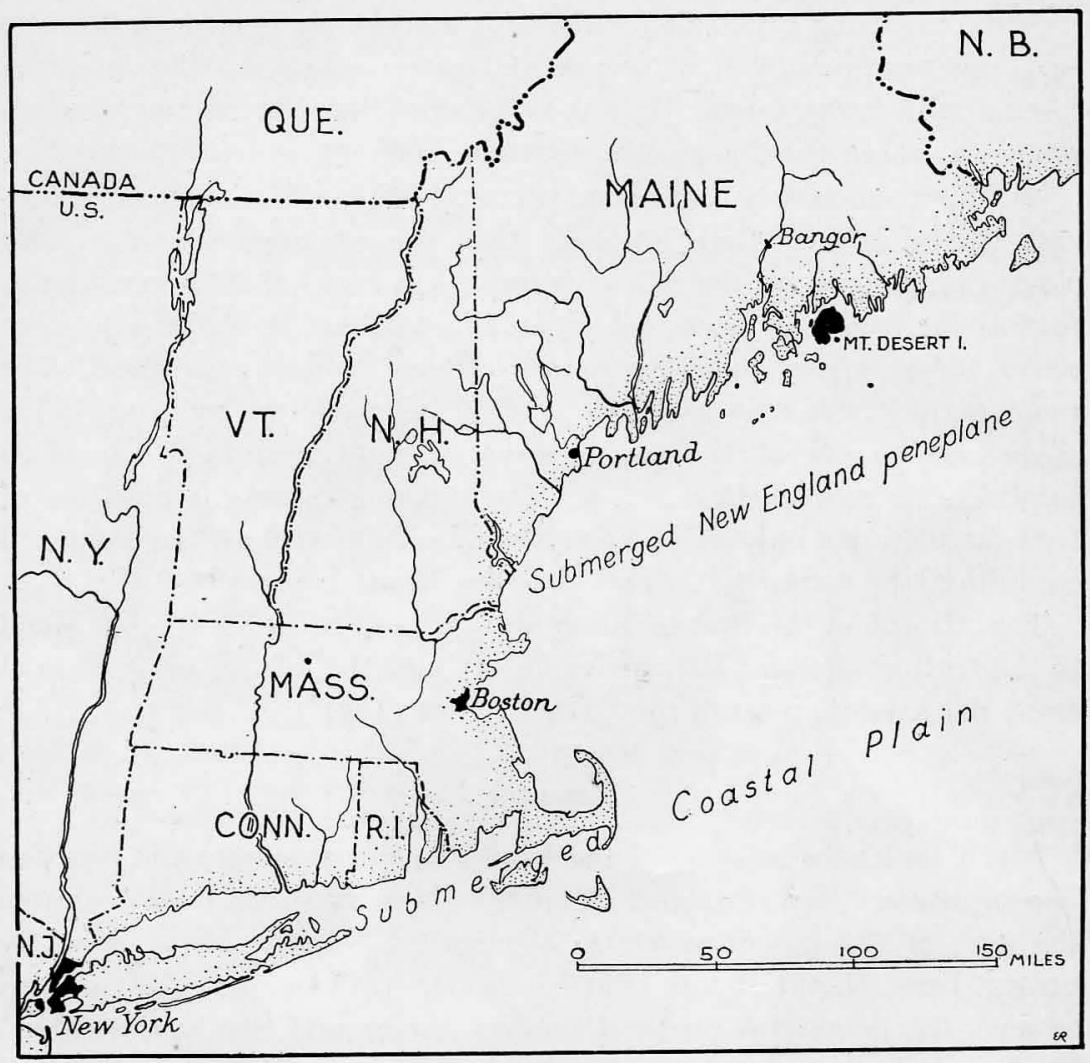

FIg. 1.-Location map of Mount Desert Island.

erosional remnant or "monadnock" on this peneplane. The presence of the mountainous monadnock is due to difference in rock resistance. The central granitic mass was able to withstand the general leveling which wore down the surrounding country to a peneplane. The bevelled land was slightly uplifted, dissected into low hills and valleys, then submerged under sea level. The submergence of this rolling country accounts for the highly irregular shoreline with its countless islands and peninsulas.

Before the Ice Age the monadnock was a single east-west trending ridge. During glaciation this ridge was cut across by ten parallel northsouth trending glacial troughs. These troughs are so deep and steepsided that the ridges between them appear as separate mountains. In most of the troughs are beautiful lakes. One is carved below sea level; this is Somes Sound, which cuts the Island nearly in two in the middle. 


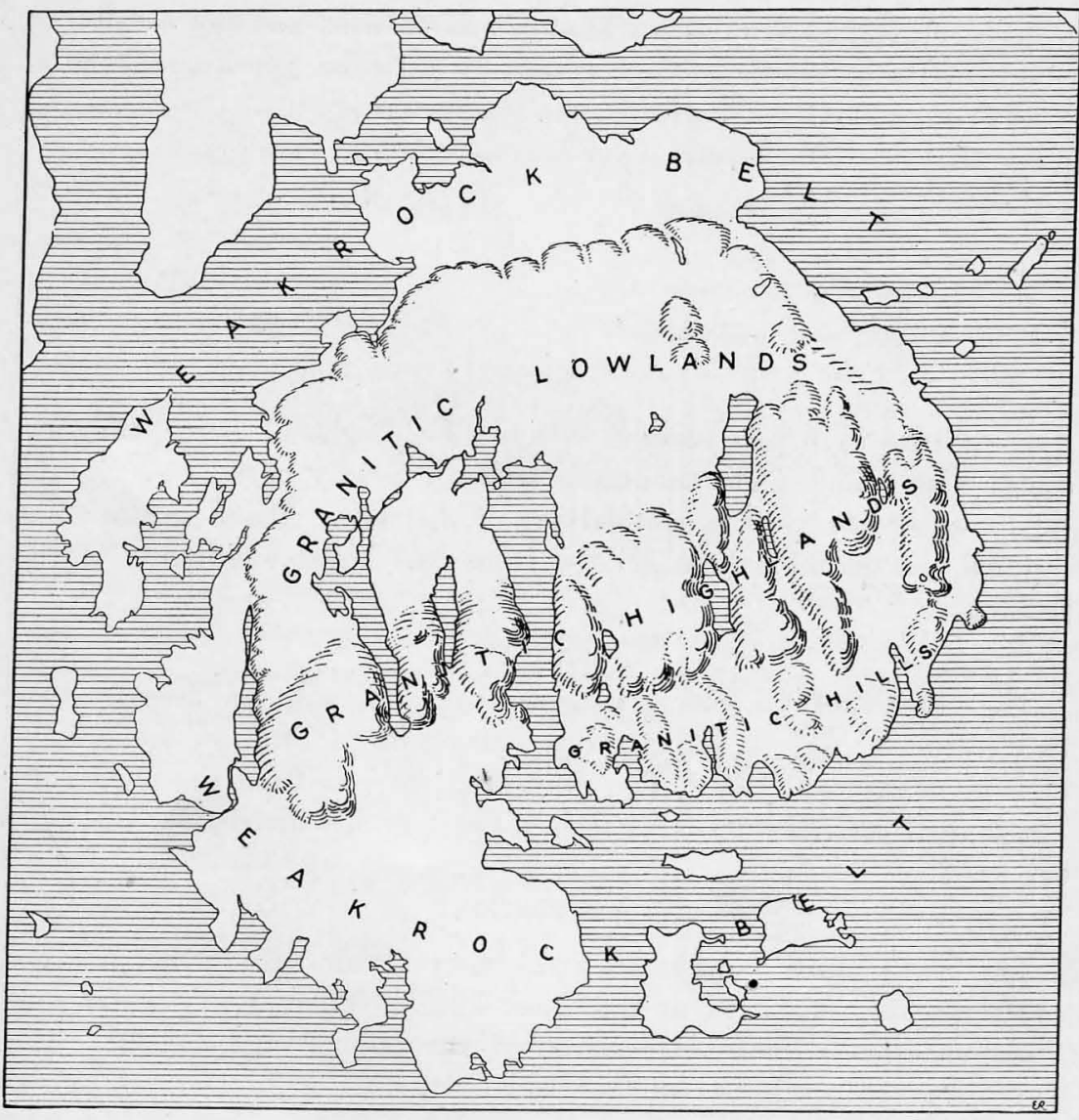

FIG. 2.-Physiographic divisions of Mt. Desert Island.

If the sea level were a few feet lower, Mount Desert Island would be a peninsula. If the sea level were a few hundred feet higher, the lowlands would be covered completely by the ocean and the monadnock would stick out as a most picturesque group of islands.

\section{Physiographic Divisions}

Not all of the central granitic area stands out as a monadnock. The peneplanation advanced far enough to level off about half of the granite. In the northern part of the Island the granite seems to be of as resistant a quality as that in the mountains, but the land is low. This granitic lowland is still higher than the surrounding weaker rocks from which it is separated by a low rim or scarp. 
The southeastern part of the granitic mountains, possibly because of some structural reason, is lower and has a different appearance, and is referred to in the later discussions as the "granitic hills."

We thus have four natural divisions of the Island (see Fig. 2):

1) The granitic mountains

2) The granitic hills

3) The granitic lowlands

4) The weak rock lowlands

\section{SOIL}

The Island is in part covered with a sheet of glacial debris, very unevenly distributed. The mountain tops are nearly barren, but in the valleys there are great accumulations of material. There is also some residual soil on the Island derived from postglacial weathering of the bedrock.

\section{Climate}

The climate of the Island is generally mild, with an average July temperature of $64^{\circ}$; a January temperature of $24^{\circ}$ and an average annual temperature of $43^{\circ}$. The prevailing wind is from the northwest. The annual precipitation is 42 inches, fairly evenly distributed throughout the year.

\section{VegeTATION}

The moist climate, together with fairly fertile soil, favors a great abundance of vegetation at the lower levels. There heavy forest and thick underbrush make exploration of the Island very difficult. The forest cover conceals the smaller land forms, as cliffs, terraces, eskers and other glacial forms. On the other hand, differences in vegetation often indicate differences in the rock beneath.

\section{INHABITANTS}

There are about 7000 permanent inhabitants on the Island, approximately half of them in the town of Bar Harbor. The occupations of the scant original population were farming, fishing, lumbering and quarrying. Now the chief source of income is from the summer visitors. The population in summer is estimated to be from two to three times that in winter.

A good system of roads and a splendid system of mountain trails and foot-paths are maintained. Some of the most valuable information was obtained from cuts along the roads. The numerous quarries on the Island were also very helpful. 


\section{Lafayette National Park}

The beauty of mountain, lake and shore, a favorable climate and nearness to great centers of population attract many people. Mount Desert Island became a fashionable summer resort early in the second half of the nineteenth century and the popularity of the Island has steadily increased.

Through various gifts, due to the interest and energy of Mr. George B. Dorr, a member of one of the earliest summer-resident families upon the Island, the main part of the Island's beautiful mountain chain has been set aside as a playground of the nation, under the name of Lafayette National Park.* This is the first national park established east of the Mississippi River.

\section{Nomenclature}

The names of a number of the mountains were recently changed by the National Geographic Board upon the establishment of the Park. This new nomenclature appears on the United States Geological Survey maps and recent charts of the United States Coast and Geodetic Survey. These names are here used, the former names being given in parentheses.

The changes are indicated in the following table:

Old Name New Name

Newport Mt. ............. Champlain Mt.

Dry Mt. ............... The Flying Squadron

Green Mt. .............. Cadillac Mt.

Jordan Mt. .............. Penobscot Mt.

Little Browns Mt. ........... Parkman Mt.

Browns Mt. .............. Norumbega Mt.

Robinson Mt. .............. Acadia Mt.

Dog Mt. .............. St. Saveur Mt.

Western Mt. East Peak ........... Mansell Peak

Western Mt. West Peak ......... Bernard Mt.

The village of Somesville appears on the U. S. G. S. maps as $M t$. Desert, the name of its post office.

\section{Previous Geological Work}

Several of our most prominent geologists have visited the Island in past years and published the results of their investigations. One of the earliest papers dealing at some length with the geology of the Island is

* Since the writing of this paper the name of the park was changed by Act of Congress from Lafayette National Park to Acadia National Park. 
W. O. Crosby's "Geology of the Frenchman Bay, Maine” (9)* which describes the outstanding geological features in a most satisfactory way.

The most extensive study of the Island was made by Nathaniel S. Shaler. His results are published in the Eighth Annual Report of the United States Geological Survey, Part 2, 1886-87 (25). He prepared a geologic map of the island, studied the surface deposits, and worked out the geological history. While some of his views are not now held, his book is still, forty years after its publication, our chief source of information on the geology of the Island.

G. H. Stone in his great work on "The Glacial Gravels of Maine and their Associated Deposits" (U. S. G. S. Monograph 34) does not treat of Mount Desert Island very extensively, but his information on the adjacent region is of much value to any worker in the region (27).

Professor William Morris Davis published a chapter on geology in the "Flora of Mount Desert Island" by Rand and Redfield (14). This paper is intended for the general public and makes wonderfully clear, even for the untrained reader, the principal geological events in the history of the Island.

A short paper by Florence Bascom (4) presents a brief but fairly complete picture of the local geology.

Professor H. L. Fairchild in his "Postglacial Uplift of New England" (17) uses the Island as an illustration of his postglacial emergence theory.

Professor Douglas W. Johnson in his "New England-Acadian Shoreline" (21) gives the most detailed study of the physiography, with the most original views upon the coastal features of the Island. The present paper is largely a study of the problems raised by Professor Johnson's book.

There are several shorter articles referring to the geology and the physiography of the Island, but most of them use one or another of the works above cited as a source of information.

\section{ACKNOWLEDGMENTS}

The present study is the result of a summer's field work in 1926, made possible by the courtesy of Mr. George B. Dorr, creator and superintendent of Lafayette National Park, who covered the author's field expenses and at all times rendered the most generous aid. The work has been

* Throughout this paper the bibliographical references are designated by an italicized number in parentheses. The reader is referred to the Bibliography at the end of this paper for their elucidation. 
carried on under the direction of Professor Douglas Johnson of Columbia University to whom the author is indebted for valuable criticism and advice. Both in the field and in the office Professor Johnson gave the author the benefit of his wide experience. Two park rangers, William B. Campbell and Orient Y. Thompson, accompanied the author in most of his field work and proved to be understanding and helpful guides and companions. The author wishes to thank Mrs. L. Hugentobler, Miss B. Blauvelt and Miss G. Hargrave for their help in getting the manuscript into final form for publication.

If, despite all the help the author has received, there remain in the text phrases which fall strangely upon the American ear, it is hoped that the reader will prove indulgent toward one who has not yet fully mastered the language of his adopted land.

\section{THE GEOLOGICAL HISTORY OF MT. DESERT ISLAND}

Mount Desert Island as it stands today is a result of all the processes and forces operating on it in the past. The best understanding of the present features can be obtained by tracing its geological history. The following outline will serve to summarize events which will be elaborated in the following chapters. As the author in his study necessarily restricted himself to the field of physiography, the petrographic facts here given are based largely on Shaler's work.

The history of the Island can be divided with some generalization into three epochs, very unequal in duration:

1. The constructive period, which includes all the time, up to the early Mesozoic, during which the rocks of the Island were being formed.

2. The great denudation to the end of the Tertiary, when erosional processes dominated.

3. The Ice Age, during which the land forms attained their present appearance. The relatively short post-glacial time is here included.

Although these periods may be related in duration of time somewhat as $100: 10: 1$, their relative importance in the sculpturing of the present land forms is rather in reversed proportion.

\section{The Constructive Period}

\section{THE FORMING OF THE WEAK ROCKS}

The first important event in the history of the Island was the formation of the extremely complex series now constituting the peripheral belt of weaker rocks. Generally there are more schistose formations 
west and south, more flagstones and shales on the north and east. They are not easy to identify because of subsequent igneous intrusions, which affected these rocks profoundly. Certainly they do not represent a single period of deposition and are probably of very different age. The "sedimentation-uplift-peneplanation" cycle has been repeated perhaps several times. But because the sequence of the beds has not been worked out with certainty, and further because from the physiographic point of view such sequence is not important, these rocks are treated here as one series. The general term "weak rocks" is used for all pre-granitic rocks, which are differentiated by Shaler into the Bartlett Island, Schooner Head, Bar Harbor, Cranberry Island and Sutton Island series.

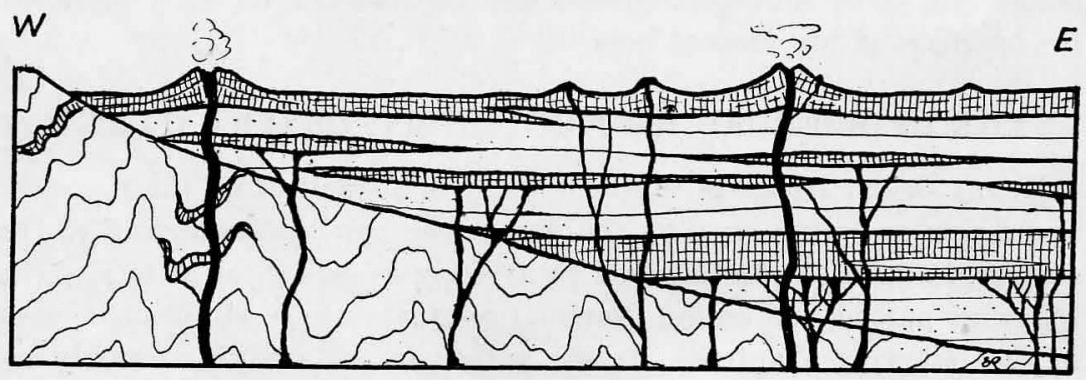

FIG. 3.-The weak rock series. Schistose rocks on the west and sediments on the east, both indurated by basic igneous intrusions. The peneplane between the schist and sediments is hypothetical.

The age of the weak rock sediments is not known, but they may be Pre-Cambrian. No fossils are found, even where the rocks are least disturbed. Similar rocks found in Penobscot quadrangle are tlought to be early Paleozoic (6-map).

\section{THE BASIC ROCKS}

The history is complicated by periods of vulcanism developed on a vast scale, and perhaps repeated in widely different ages. The sediments were extensively penetrated in places by igneous rock, mostly of basic composition. It is often impossible to tell where the igneous material ends and where the sediments begin. The igneous rocks are a confused mixture of intrusive sheets, lava flows, breccias, tuffs, while several systems of dikes can be differentiated. These rocks have one character in common, which is most important from a physiographic point of view : all offer only moderate resistance against erosion. 


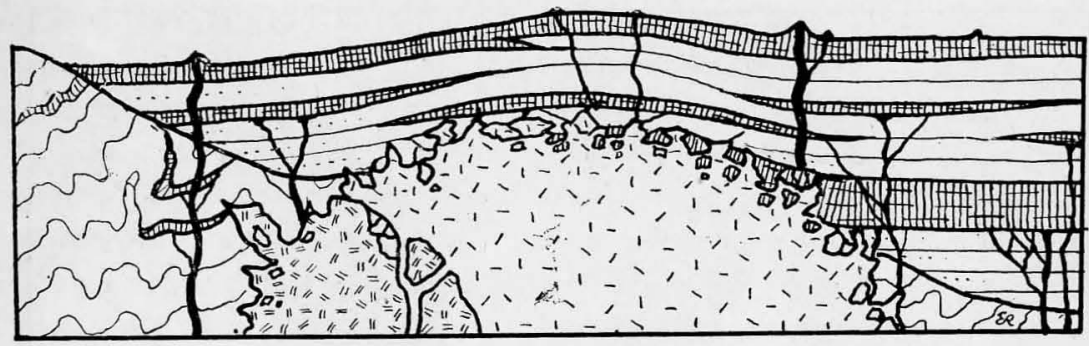

Fig. 4.-The granitic intrusion. Note the irregular contact, with penetration and incorporation effects.

\section{THE GRANITIC INTRUSION}

The most important event in the history of rock-making was the great granitic intrusion. The molten mass forced its way through the older rocks, partly uplifting them, partly melting and incorporating great chunks of them. The whole mass crystallized into a coarse hornblende-biotite granite.

Though less complicated than the earlier basic intrusions, the granitic rocks are not of uniform character. The borders of the granite are gray whereas the general mass is pink, while in the western part of the Island the granite passes into gabbro-diorite.

The granitic mass of Mount Desert Island is not an isolated occurrence. As shown on the map by T. Nelson Dale (12-map), it is a part of an extensive intrusion or batholith which extends from New Brunswick to Penobscot Bay. (The granites south of Penobscot Bay are younger.) This granite mass crystallized deep below the older rocks, and the roof or ceiling of older rocks was very irregular, with masses of the roof extending down into the granite, and "cupolas" of the granite projecting up into the roof cover. Erosion was not able to reach the granite everywhere, hence only the more outstanding cupolas are stripped of their old rock cover. Such a cupola is Mount Desert Island. The continuity of the granite below is testified to by the granitic dikes and patches in the weak rock belt.

The age of the granitic batholith is thought to be early Devonian. Granitic pebbles are found in the late Devonian Perry formation in eastern Maine, while such pebbles are absent in the Silurian formations (26-p. 20).

\section{FOLDING AND FRACTURING}

There were doubtless mountain-making periods before the granitic intrusion. Presumably also there was a great amount of earth move- 


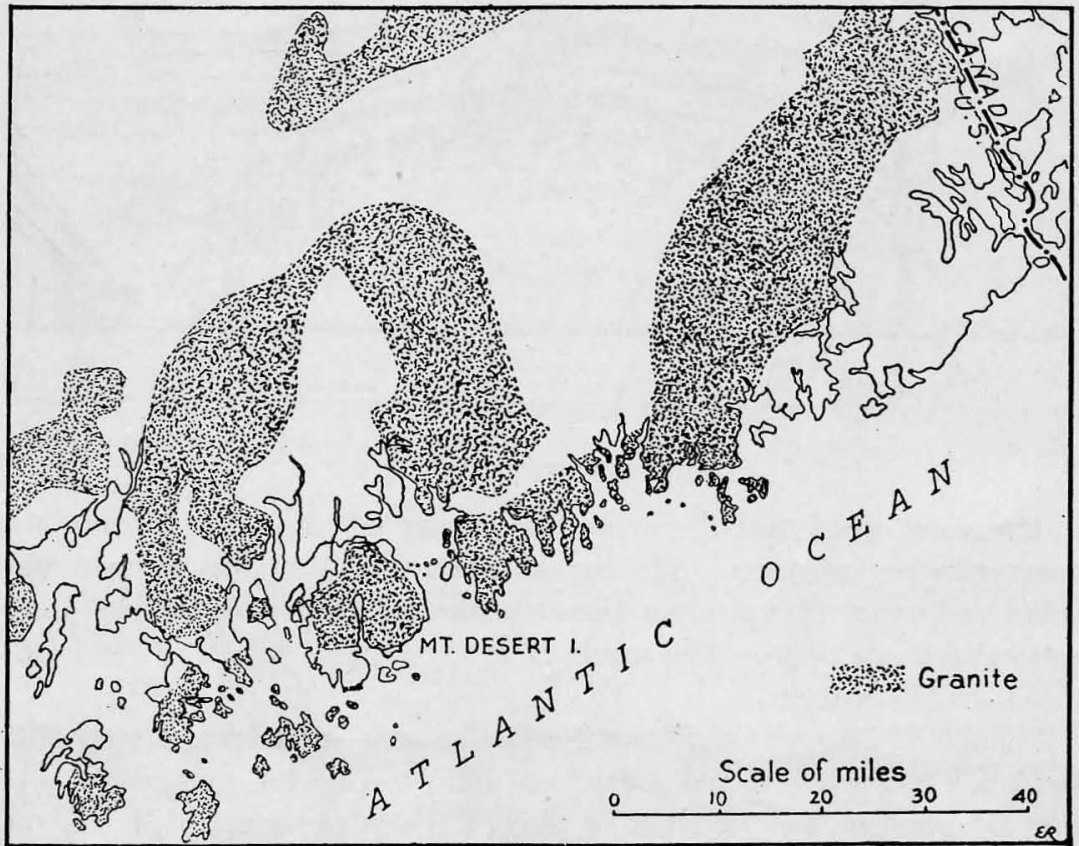

FIG. 5.-Map of Eastern Maine showing distribution of the granite (after T. Nelson Dale). Mt. Desert may be a "cupola" of the big Maine batholith.

ment during the granitic intrusion, and certainly important disturbances occurred after the granitic masses had cooled and crystallized.

During these earth movements the sediments and associated basic igneous rocks were thrown into open folds, anticlines and synclines. The igneous rocks were cracked into a mesh-work of joints, in addition to the original columnar jointing which characterized some of them. The flagstones and schists were cracked into minute prisms. The big mass of granite offered more resistance. By its nature folding was not possible. Most probably it suffered torsional stresses and a joint system developed with vertical master-joints trending $\mathrm{S} 20 \mathrm{E}$, dividing the granite into huge blocks. There was álso occasional movement along the joint planes producing faults.

The last great disturbance is probably to be correlated with the Appalachian Revolution at the close of the Paleozoic period. It is believed that at this time the region was lifted high above sea level.

\section{LATER INTRUSIONS}

Into the north-south ( $\mathrm{S} 20 \mathrm{E}$ ) cracks igneous material was forced, (erystallizing as a light pinkish, fine-grained feldspar-quartz material. 


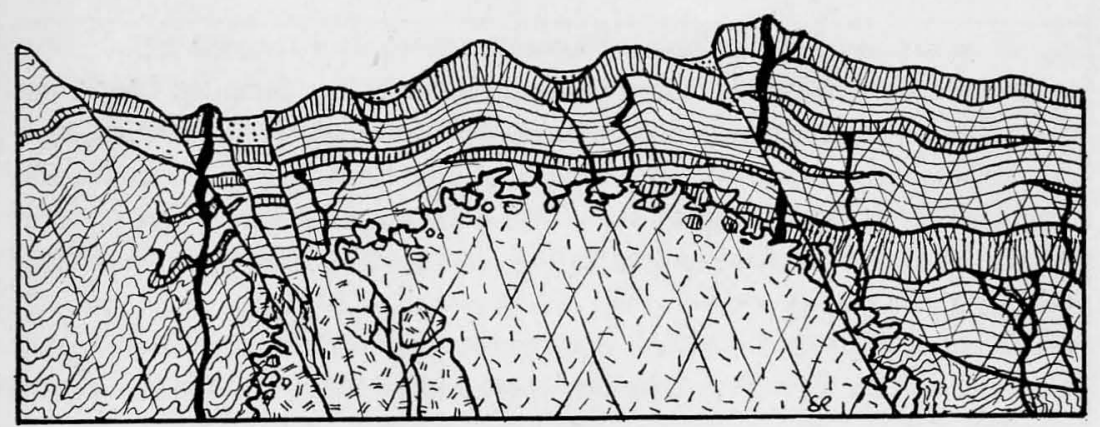

FIG. 6.-The postgranitic disturbance, showing folding, fracturing and faulting of the rocks.

forming the "pink dikes." These dikes are common in the granite, but not very apparent because of their similar color. In spite of the abundance of quartz, they are not resistant against erosion because of their prismatic joints and brittle character.

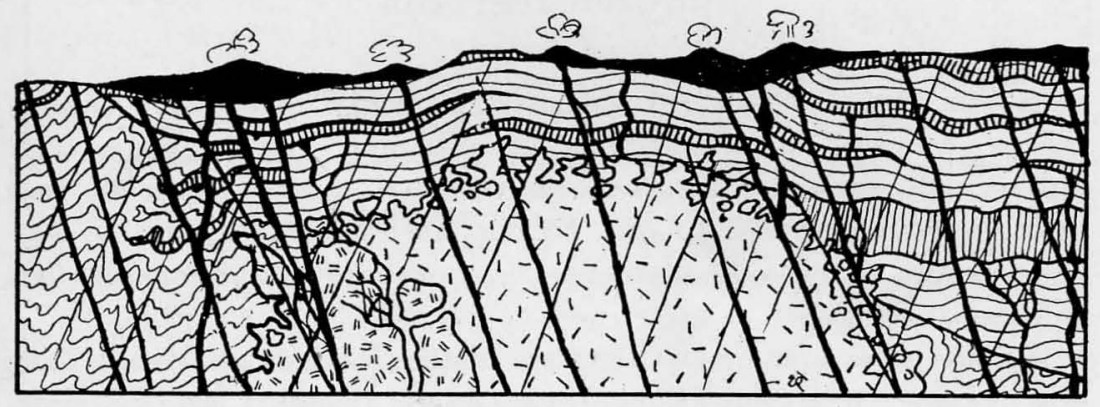

Fig. 7.-The dikes and the lava flows which probably covered much of the surface. The dikes are parallel (nearly N-S) and rather evenly distributed.

More apparent are the dark diabase dikes. These are 2 to 20 feet thick, and their direction is so uniformly S $20 \mathrm{E}$ that they can be used with fair certainty as a compass. The diabase dikes are less resistant than the granite, and exerted a great influence in directing stream erosion, and later that of ice. Their distribution is surprisingly uniform. There is scarcely a stretch of a mile on the Island where at least one cannot be found. These dikes are also present in the older rocks, but because of similar color and the presence there of older dikes, they are not so evident.

THE CONTINUITY OF THE TRAP SHEET OVER NEW ENGLAND

The size, color and texture of the diabase dikes as seen in the hand specimen are just the same on top of Cadillac (Green) Mountain (1532 
ft.) as at sea level. We have to assume the dikes extended a long way upwards. They may even have reached the surface, forming lava flows. The presence of abundant trap material in the highest mountains midway between the extensive trap sheets of the Bay of Fundy and of the Connecticut Valley is significant. Possibly we find here some support for the theory of a former continuity of the trap flows over much of New England.

The dikes represent the last important rock-building process on the Island. By analogy with similar occurrences they can tentatively be assigned to the Triassic period.

There was a still later effect: a filling of the cracks with green epidote vein material. With this closes the constructive period of the region. Smaller disturbances occurred in later times, and the diabase dikes are often displaced. But the later earth movements of importance were of a regional (epeirogenic) nature.

\section{The Great Denudation}

THE EROSION

Erosion naturally occurred whenever the region rose out of the sea, and perhaps was at the maximum at times when the mountains were highest; but it was not always the dominating process. When the constructive process ceased, erosion became the dominating process, and has remained so up to the present time, except during occasional periods of regional uplift.

We have to assume that at the close of the Constructive Period there existed above the present mountain tops several thousand feet of granite, a great mass of older rocks, as well as later dikes and possibly flows of trap.

The rain and rivers slowly wore down the mountains, until the less spectacular but untiring erosive processes had destroyed much of the work accomplished by the mountain-making processes. "Gutta cavat lapidem, consumitur annulus usu." The lava flows, if there were any, are swept away; gone are all the old rocks above the granite; and erosion has bitten deep into the granite itself. The same prolonged erosion at first deepened valleys, then broadened them, and after passing through the young, mature and old stages of the river erosion cycle, produced a low undulating plain near sea level-a peneplane.

\section{THE JURA-CRETACEOUS PENEPLANE}

There are many indications in the eastern United States that the mountains of the Appalachian Revolution were worn down to a pene- 
plane in the Jurassic period or at least by early Cretaceous time. This is not the New England peneplane but an older level, which appears now only along the Fall Line and supposedly on the top of certain mountain ranges (3).

The lowlands of Mount Desert Island are a part of the New England peneplane, often called the "New England Upland" because inland from the coast it rises high enough to give a plateau-like upland. If there was an earlier peneplane than the New England, traces of it might be found on the Mount Desert mountains. Did the granitic mass of Mount Desert Island resist at this earlier time the general peneplanation, and stand out as a monadnock; or was it worn down to the same level as the surrounding country? In the latter case, are traces of the older peneplane preserved? These are open questions.

There are some indications in favor of the view that traces of the older Jura-Cretaceous peneplane are preserved. Looking over the flat tops of the mountain ranges we find that they show a certain accordance of elevation. (Sargent Mt. 1344', Pemetic Mt. 1262', Cadillac Mt. 1532', Flying Squadron (Dry) Mt. 1268', etc.) Furthermore, the biggest mass of mountains in the center (Sargent Group) has not the highest elevation, as we might expect to be the case if erosion had been the only process at work on homogeneous material in one cycle. Although the flat tops of the single ridges might be explained by planation of the over-riding ice sheet, the accordance of elevations together with the evidence of the Sargent Group indicate that there was an old peneplane surface not far above the top of the present granitic mountains. Perhaps this level was the ancient Jura-Cretaceous peneplane.

Near the end of the Mesozoic the Atlantic coast was uplifted and a new cycle of erosion was initiated.

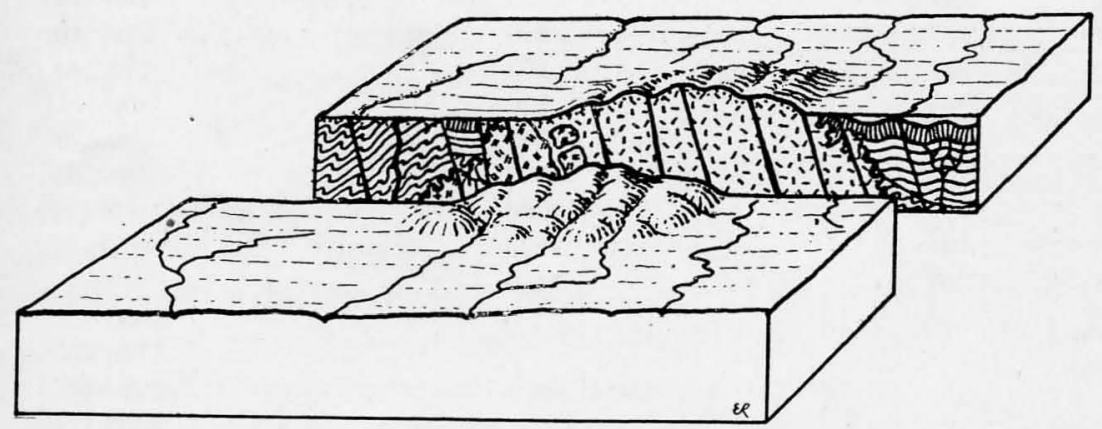

FIG. 8.-The New England peneplane with Mt. Desert range rising as a monadnock above it. There may have been an earlier peneplane at the height of the mountain tops. 


\section{THE NEW ENGLAND PENEPLANE}

If we connect the ridge crests and the hilltops of New England (disregarding the valleys as the results of later dissection), we get a gently undulating plane, with occasional isolated mountains rising sharply above it. This plane bevels all kinds of geological structures, and is called the New England peneplane. The region around Mount Desert Island is a part of this peneplane and the Mount Desert mountain range is a monadnock on it.

IS THE NEW ENGLAND PENEPLANE OF MARINE ORIGIN?

Barrell (3-pp. 40\%-428) suggested that the New England peneplane was not eroded by rivers and rain, but was carved by the waves of the ocean. His evidence consisted chiefly of supposed terraces found in different parts of southern New England. He did not state the height of the terraces at Mount Desert Island and they can be projected only with due allowance for possible local disturbance.

If these terraces really exist and are of marine origin, there is no better place to see them than on Mount Desert Island, which was more exposed to prolonged action of the waves than places now farther inland. Before Barrell undertook his study, Shaler found a number of benches on the Island which he thought to be of marine origin. But a comparison of Barrell's figures for terrace heights with those of Shaler appears to show nothing more than occasional fortuitous agreements, as indicated in the table herewith:

Terrace levels as described by :

Barrell in southern New England

Shaler

at the head

of the terraces

projected to the

Connecticut shoreline

120

240

400

530

680

800

1000

1200

1450

on Mt. Desert
Island
90
$165-185$
$220-240$
$270-290$
300
$380-430$
$480-500$
$?$
$?$
$?$
1000
$1140-60$
$1210-40$
$1280-1320$
$1460-80$
1510


Both Shaler and Barrell give wide limits of variation for the altitudes of their terraces. The uncertainty of Barrell's figures is still further increased by projecting them so far from the areas of his study. Furthermore, at both places the supposed terraces lie very close to each other. Under these conditions an apparent agreement of the figures would in no case be conclusive.

The author made a careful investigation of the supposed marine benches of Mount Desert Island. The result, unfavorable to the marine theory, will be discussed in a later chapter.

There is some direct evidence for the non-marine origin of the New England peneplane: Mount Desert Island is a nearly circular granitic area surrounded on all sides by weaker rocks. Had the peneplane been carved by waves, the main attack must have come from the south, and the mountain monadnocks, as remnants left by incomplete marine erosion, should be more toward the northern side of the granitic area. As a matter of fact the monadnock mass is nearer the southern margin.

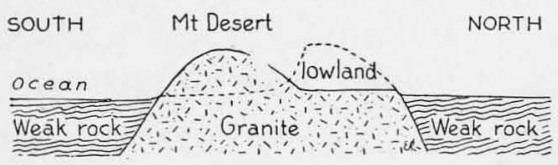

Fig. 9. - The actual position of the Mt. Desert monadnock in relation to the extent of the resistant granite area (solid line). If the New England peneplane had been carved by waves, the monadnock should be on the northern side of the granitic area, as indicated by the broken line.

(Fig. 9). Barrell's theory of the marine origin of the New England peneplane appears to find no support on Mount Desert Island.

\section{THE PROBABLE EXPLANATION OF THE PRESENCE OF MOUNT DESERT MOUNTAINS}

There are in eastern Maine hundreds of square miles of granite most of which was very well peneplaned. The question arises: Why were the Mount Desert mountains able to resist erosion?

The explanation may lie in the peculiar position of Mount Desert Island, shown on the map, Fig. 5. The granite cupola of Mount Desert Island is surrounded on all sides by a broad belt of weak rocks, and these weak rocks diverted the large rivers coming from the north. Only the small rivers originating on the granite itself carried out the work of erosion upon the mountains, naturally at a slower rate. A repetition of similar conditions is found on Isle de Haut in Penobscot Bay. 
Another possibility is that the original mass of granite was here higher than at any other place in the region. Thus Mount Desert Island might be the high part of a high cupola.

A third possibility, and perhaps the most probable, is that differentiation of the granite resulted in areas of varying resistance, and that the Mount Desert range represents a phase of peculiar durability. The test of this theory is not simple, because variable degrees of weathering in collected samples of the rock may be due to purely local causes, and afford no evidence as to the behavior of large masses; nor is hardness of a hand specimen any criterion as to the resistance the same rock will offer to long-continued weathering and erosion. It can only be said that there do exist marked differentiation phases of the granite, and that, for example, a finer gray facies is fairly widespread in parts of the granitic lowland, whereas the granite of the high mountains is prevailingly coarser and of a color varying from red to pinkish gray. On the other hand, finer gray granite is found in the mountains and coarse red granite in the lowlands. Only a detailed petrographic study of the whole area, such as lay beyond the scope of the author's study, would solve this problem.

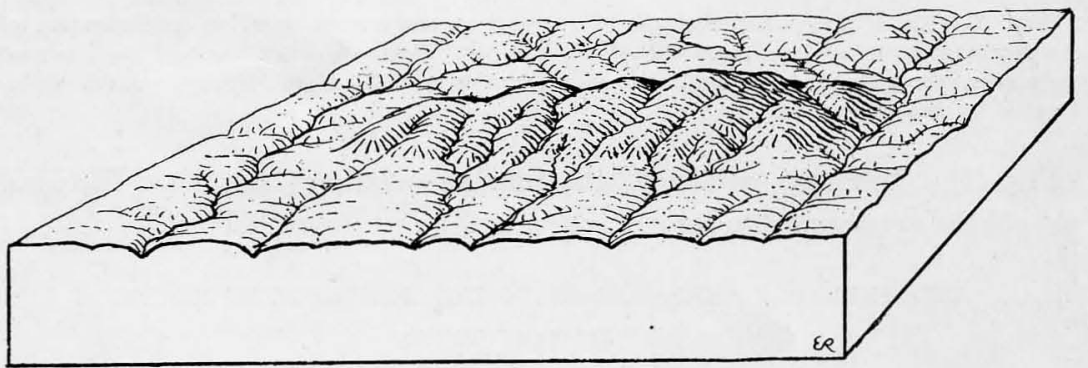

FIG. 10.-The uplift and dissection of the New England peneplane.

THE UPLIFT AND DISSECTION OF THE NEW ENGLAND PENEPLANE

After the New England peneplane was formed the whole region was uplifted and tilted to the southeast. The sluggish rivers were rejuvenated, and the peneplane was redissected into hills and valleys. This period of dissection could not have been extremely long; because the rivers in the Mount Desert region did not pass beyond the sub-mature or mature stage of development. It succeeded, nevertheless, in lowering the average level of the weak rock belt somewhat below the granitic lowlands. 
The same dissected character of the surface can be traced by soundings far out in the sea. The shoreline was at this time perhaps as far out as the Banks.

\section{The Ice Age}

Wherever we go on Mount Desert Island, we are reminded in some way of the great Ice Age. The cliffs, the lakes, the soil, even the plants and animals, bear witness to this period of the earth's history.

As the ice advanced from the north, it encountered few obstacles on the New England peneplane. The general southward slope and the low hills were easily traversed. The first real obstacle to be encountered in this region were the Mount Desert mountains, extending in a direction transverse to the motion of the ice. We have to imagine the mountains at this time as a maturely dissected range with an uneven crest and with deep valleys and dividing spurs on both flanks. The ice ascended the valleys of the northern flank and spilled over the crest, at first, of course, in the saddles, whence long icy tongues descended upon the southern lowlands.

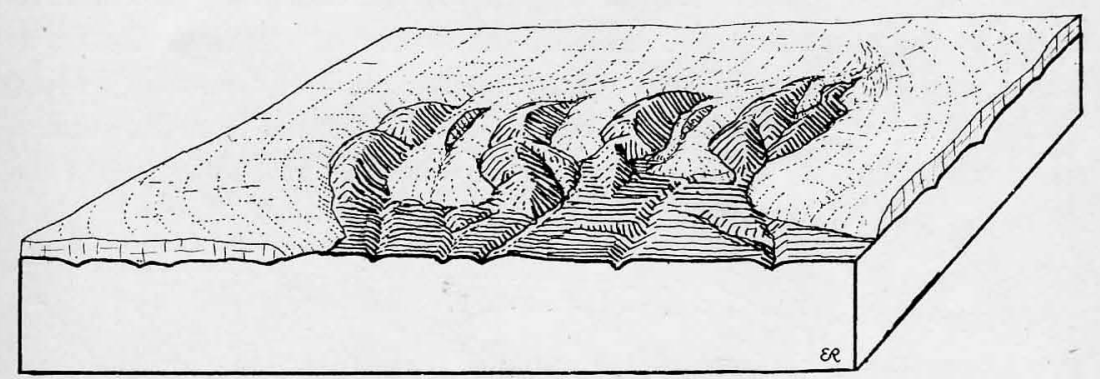

FIG. 11.-Advance of the ice through the Mt. Desert range.

For a long time the ice carved its spillways deeper and deeper into the saddles until it had cut sufficiently deep for more effective discharge, despite the increasing thickness of the ice. Such is the origin of the deep glacial troughs which give so unusual an appearance to the Mount . Desert range. Only when the thickness of the ice exceeded the height of the mountains were the crests buried under a slowly moving ice sheet several thousand feet thick.

At this stage the ice movement changed its direction. This is recorded in the asymmetry of the mountains and in the form of the ice-carved ledges. In the beginning the ice was guided by the direction of the valleys, which was transverse to the main crest and coincided with the 


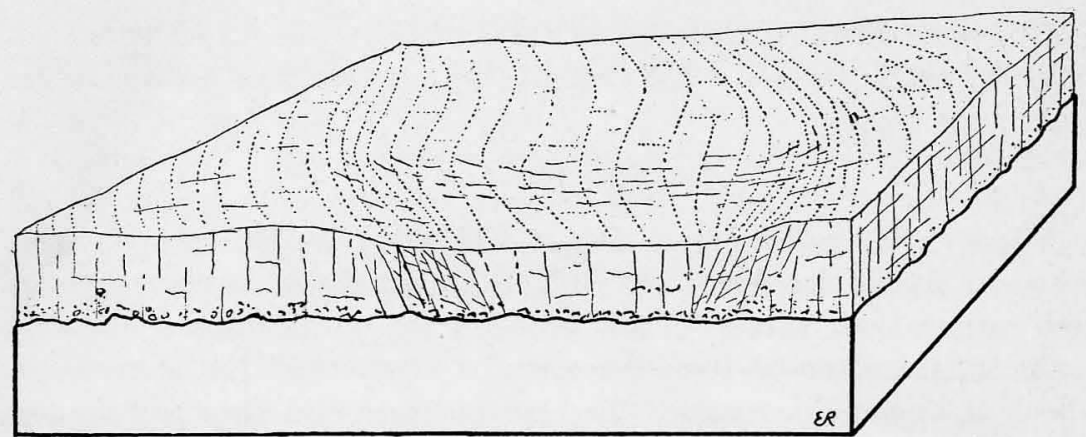

Fig. 12.-The ice over Mt. Desert. The range is completely buried by ice. At this stage the ice is supposed to have moved SE.

direction of the north-south dikes. Where the ice extended above the mountain tops, it could not be controlled further by the topography, but followed its own general direction of flow, which was more to the southeast.

During glaciation-probably due to the enormous weight of the icethe earth's crust yielded and the region was depressed several hundred feet. As the climate became milder, the supply of ice from the north ceased, and the great thickness of ice melted gradually down. During the vanishing of the ice sheet the earth's crust, liberated from its burden, rose again. This elevation appears to have been in full swing when the ice melted away from Mount Desert Island.

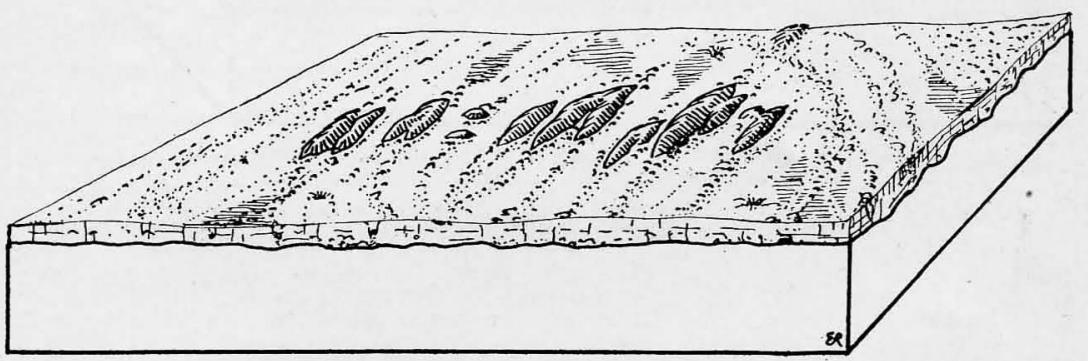

FIG. 13.-Vanishing of the ice sheet, with concentration of debris, and moraines trailing from the reappearing ridges.

At this stage of the vanishing ice we have to imagine the Island somewhat similar to the present coast of Greenland. The ridges were free from ice, but in the deep valleys long ice tongues extended toward the sea from the vast frozen fields behind. The Island was still depressed and the waves of the ocean swept away the glacial debris from the out- 
standing ridges. The height of this post-glacial sea is found to be about 220 feet above the present sea level, as will be shown in the next chapter.

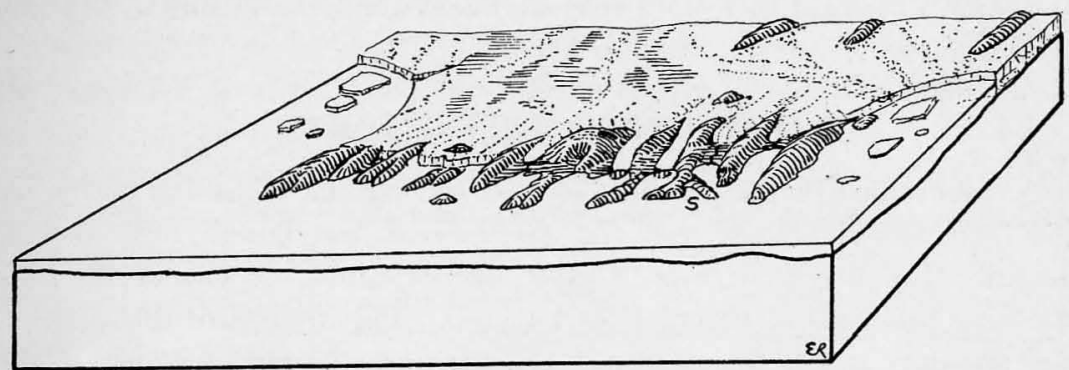

Fig. 14.-Mt. Desert Island at the beginning of post-glacial time. Ice iongues lingering in the valleys, while the ridges are free from $i \cdot$.

As the ice melted, it dropped its load. The mountains and lowlands were covered with glacial debris, and overloaded rivers started to transport and sort the material. Stream deposition of the ice-carried material may well have proceeded on a scale unparalleled at the present time.

The drainage of the Island was completely changed by glaciation. Some of the old stream channels were destroyed, and the deep glacial troughs offered new channels for the run-off. The rivers started to remove some obstructions from their courses, but that this process has not advanced very far is shown by the many lakes and swamps remaining on the Island at the present time.

Life took possession of the Island again. In the sheltered coves marine pelecipods and barnacles of an arctic type appeared. Vegetation took hold on the rocks; forest cover developed and checked the rapid stripping of the mountain sides. Fish appeared in the lakes and wild animals reached the Island and inhabited the forests. In consequence of its separation from the mainland, which was even more pronounced in earlier times than now, the flora and fauna of the Island are somewhat different from that of the mainland and still retain a more arctic character. Finally men appeared on the Island, a not negligible geological agency. Wholesale deforestation, which promoted erosion of the soil, the damming of lakes, the building of breakwaters and especially agricultural activities influenced many of the normal geological processes.

Most of the changes in their end result were very fortunate for the present inhabitants of the Island. The lofty mountains and the deep glacial troughs with their over-steepened slopes, the beautiful lakes, the 
deep sheltered bays, the high-cliffed headlands invest the Island with unparalleled beauty, so that it is one of the places most highly favored by people who want to restore body and soul amid the primitive features of nature.

\section{THE UPPER MARINE LIMIT}

As mentioned in the previous section, during the vanishing of the ice the land was depressed and the sea covered the Island to a certain height. The height of this "Upper Marine Limit" is one of the outstanding problems of Mount Desert Island. The interest of the question lies not only in its bearing upon the general geological history of the region, but also in the fact that nearly all geologists who have studied the Island have expressed different opinions on the subject.

\section{Review of the Literature}

Shaler (25-p. 102\%) carried the post-glacial marine limit up to 580 feet, and he thinks that the sea reached during some interglacial times above the highest peaks of the Island, over 1500 feet. His evidence is based on supposed marine cliffs and benches in the granitic mountains.

No one of the later investigators went to such an extreme. Davis (14-p. 69) thought that the marine limit exceeded 300 feet. He says: "Beds of stratified clays bearing marine fossils are found on the main land up to 200 feet." He arrives at this figure by "judging the relation of these clays to the washed gravels and sand on higher slopes." $\mathrm{He}$ also points out that the submerged condition could not have lasted long.

Bascom (4-pp. 124-26) places the upper marine limit at 350-400 feet. She found that the present rocky coast shows "(a) Sea cliffs and caves and a bench, bearing cliff debris on its outer slope; (b) Chasms bearing sand and pebble beach on their upper end; (c) Sand and clay deposits in protected places." She observed similar features at higher levels, and on this evidence she enumerates the following benches:

$$
\begin{gathered}
90-100^{\prime} \\
165-200^{\prime} \\
250-290^{\prime} \\
300-340^{\prime}
\end{gathered}
$$

She also found ill-defined benches of doubtful origin at 380, 430, 480800 , and above a thousand feet.

Stone (27-p. 48) made a thorough study of the question on the adjacent mainland and nearby islands. His upper marine limit is 230 feet. 
He found round (beach) gravels below the limit, and angular (glacial) gravels above. The change is rather abrupt in sheltered places on Isle de Haut at 220 feet.

Fairchild (17-p. 628) placed the upper marine limit at 250-260 feet. $\mathrm{He}$ based his conclusions on the nature of the post-glacial sediments, especially on delta deposits.

Johnson (21-pp. 135-40) doubted the marine origin of the higher cliffs of Mount Desert Island, including the Cadillac Cliffs. He does not give any figure for the upper marine limit, but recognizes the existence of marine forms at the lower levels. He characterizes the present shoreline as a young shoreline of submergence, recognizes that there was at least one submergence and one emergence during post-glacial time, and believes the actual history was one of more complicated oscillations of level.

\section{The Cliffes of Mount Desert Island}

Many of the geologists searching for the marine limit were looking for wave-carved cliffs and benches above present sea level. There are a great many cliffs on Mount Desert Island, at every possible level. There is even some resemblance between these cliffs and the cliffs of the present shoreline. Furthermore, they are most numerous on the south-facing side of the Island, which is also the side most exposed to wave attack.

There is an essential difference between the cliffs of the present shoreline and the cliffs above. The present shoreline, with few exceptions, lies entirely in the weak rock belt, whereas the cliffs on land are mostly in the granite. In the few places where the granite is exposed to wave attack, it is a rather surprising fact that the granite does not tend to form steep cliffs, but slopes rather gently under sea level. The two types of granitic shoreline-the Baker Island type (which is entirely flat and has a boulder beach above sea level, see Fig. 31), and the Bass Harbor type (which consists of thunder holes alternating with ridges but slightly altered by wave action, see Fig. 35)—will be discussed later, but neither of them bears any similarity to the granitic cliffs in the mountains. The high cliffs of the southeastern shore do not belong strictly to the granitic shoreline because they are on the contact zone of the granite with the weak rocks.

When we examine closely the cliffs in the mountains, we find vertical walls sometimes hundreds of feet high. They do not seem to be related, however, to any particular level; in fact, if one selects at random any level, there can usually be found cliffs at that level. On such grounds almost any level can be regarded as an ancient shoreline. 
The most characteristic feature of a marine cliff is the well-defined base at a persistent level. If the present shoreline were elevated, nobody could fail to recognize it by the persistency of its level; but the most striking feature of the cliffs in the mountains is their lack of persistence at a given elevation. Their bases instead of lying in a horizontal plane, are nearly always sloping.

The presence of cliffs in the mountains can be fully accounted for by regarding them as the work of the continental ice sheet. Some of the cliffs are clearly the over-steepened sides of glacial troughs. The steep cliffs of the mountain sides facing south are reasonably explained as the result of glacial plucking.

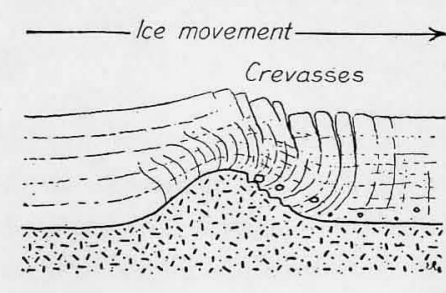

FIG, 15.-Shock and lee action of ice moving over a hill.

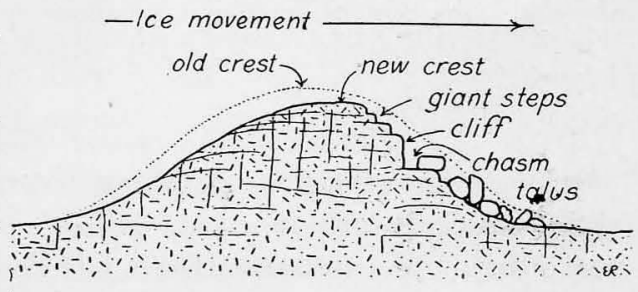

FIG. 16.-Formation of giant steps, clifis and chasms. The stoss side will be smoothed and the crest pushed slightly forward.

\section{Giant Steps}

The granite of Mount Desert Island is separated into huge, regular blocks, with straight vertical and slightly curved, more or less horizontal joints. As a result of this, while a mountain may show a very smooth rocke moutonnée form on its northern slope, on the southern slope the surface is apt to be cliffed in huge steplike terraces, for which the local name, "giant steps," is here used. The formation of giant steps is shown in Fig. 16. Because the joint planes of the granite are never exactly horizontal, the giant steps are also sloping; and this is the reason their bases are rarely horizontal-as they would be if waves had carved them.

\section{Chasms}

There are a great many chasms in the granitic mountains, and these have been explained (4-p. 125) as significant of marine action such as has formed the chasms of the present shore. There is an important difference, however: the chasms of the present shore are perpendicular to the direction of the shoreline (Fig. 38), but in the mountains the chasms 
are usually parallel to the base of the cliffs. They represent imperfectly developed giant steps, where the rock, forming the outer wall of the chasms, has not been fully removed by ice, but only moved a little distance away, as shown in Fig. 16. In other words, these chasms are widened cracks. The marine chasms are derived from removal of the rock material between two parallel joints.

There are also chasms which originated in post-glacial time. The oversteepened slopes in the granite have a very imperfect equilibrium; big masses of rock become easily parted from the parent ledge and slide downward upon the sloping joint planes by their own weight, aided perhaps by frost, snow, or the pressure of the roots of trees. The origin of these chasms is usually easily recognizable.

\section{The Tilted Rock}

There is a feature on the eastern slope of the Cleft which has repeatedly been referred to by the advocates of the marine origin of the cliffs (25-p. 1019, 4-p. 126). The Tilted Rock is a detached mass, separated by a chasm from the main ledge, and the uppermost stone of

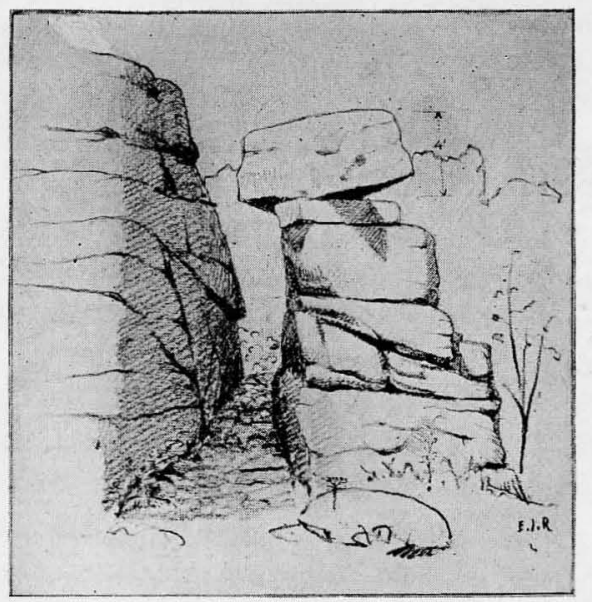

FIG. 17.-The Tilted Rock.

this mass is turned from its original position about 60 degrees. This torsion has been attributed to the action of waves. Johnson (21-p. 135) recognized the non-marine origin of this rock, and the author's examination confirmed Johnson's opinion. From the diagram, Fig. 18, it is clear that the force which turned this rock did not act from below, as a 
marine origin would postulate, but from above. The most natural explanation is that snow accumulated in the triangular wedge above the rock, and its weight was more than sufficient to turn the rock around. That the force required to do this was not necessarily too formidable is
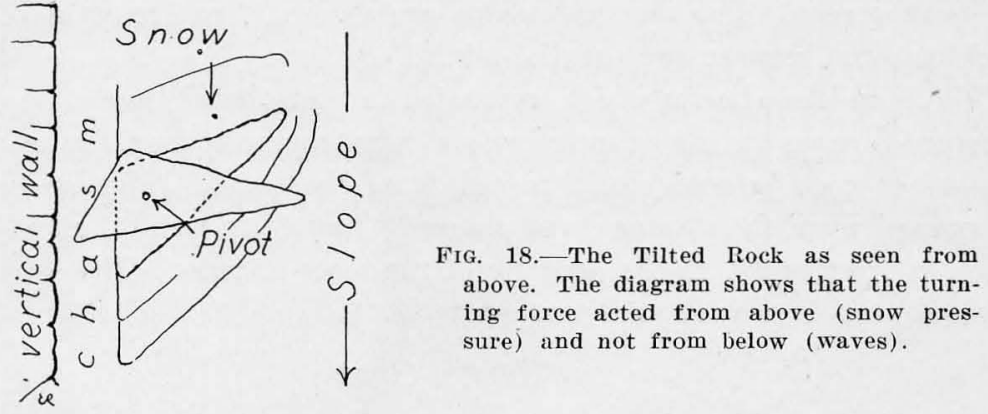

shown by the fact that the children of Otter Creek objected to the disorderly behavior of this rock and threw it down from its pedestal. But the park officers did not want to lose one of the interesting features of the Island, and replaced the rock in its tilted position.

\section{The Cadillac Cave}

Another case, cited by Shaler and Bascom as proof of former marine action, is a cave at the base of Cadillac Cliffs. Cadillac Cliffs are on the eastern slope of the Gorham Mountains and have a N-S trend. The base of the cliff starts at an elevation of 180 feet and rises to 300 feet. At an elevation of 260 feet (determined by barometer) is a cave at the base of the cliffs, in the back part of which are gravels and round boulders, lying on the floor. At first glance there seems to be some resemblance to the existing sea caves, although most of the sea caves on the present shore are formed in the weak rocks and not in the granite. The Cadillac Cliiis cannot safely be regarded as of marine origin: as Johnson (21-p. 136) pointed out, the base of the cliffs is not persistent enough in level. On the other hand, they can be fully accounted for by glacial action. This particular site seems to be the side wall of the glacier coming from the Tarn. The glacier was moving parallel with the cliffs, and it is easy to imagine that the ice loosened a wedgelike block from the nearly vertical wall and moved it slightly, leaving the rift in the rear (Fig. 19). Another possibility is that the rift may have resulted from slipping in post-glacial time. We find similar features all over the Island in every stage of development, especially along the eastern wall of Champlain (Newport) Mountain. 


\section{Beach Deposits}

Johnson noted the occurrence of true elevated beaches at low levels. These are represented by sand and gravel deposits, one of which near Mr. Dorr's residence shows indistinct ridges, tentatively interpreted by

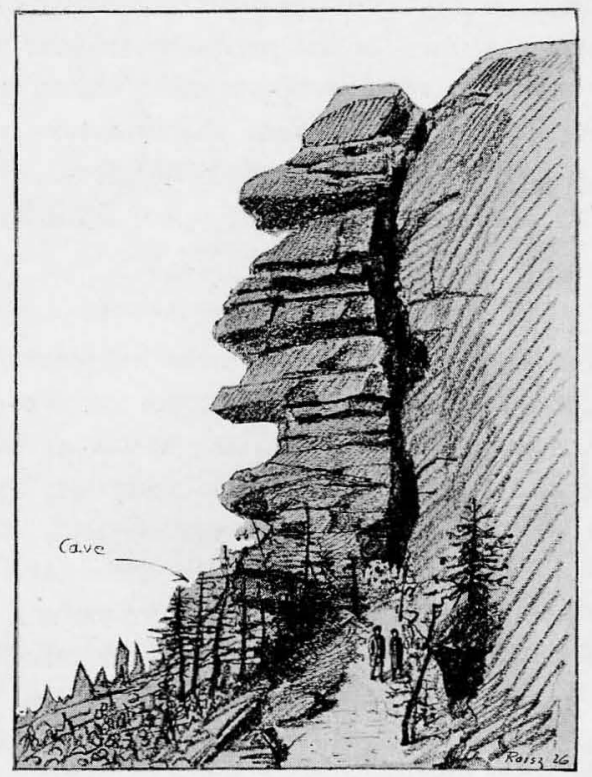

FIG. 19.-The Cadillac Cliffs.

Johnson as beach ridges. Elsewhere there are sand and gravel deposits, the nearly level upper surfaces of which may be due to wave truncation. Whatever the true origin of these obscure forms, they are all far below the upper marine limit, and give us no aid in determining that limit.

\section{Delta Deposits}

Davis and Fairchild based their upper marine limit on the height of certain delta deposits. Well assorted delta sands and gravels are found on the Island at several places, the best exposures being along Stanley Brook, where they reach an elevation of 150-200 feet.

If a clear upper limit for the delta deposits could be found, a fairly sharp upper marine limit might be determined. All the pits and quarries along the roads of the Island were carefully examined, but the result was not wholly satisfactory. Stratified sands were observed in a number of pits ranging from 80 to 500 feet in elevation; these are less well strati- 
'fied at the higher levels, better at the lower levels; but the transition is so gradual that no distinct limit could be found. The higher deposits do not show true delta structure; but this is equally true of some of the lower. In many cases the exposures were not sufficiently clear to make the structure evident. Even where an unequivocal deposit, like that so well exposed along Stanley Brook, permits the fixing of a marine limit, this is only the marine limit for the period when that particular deposit was laid down. It may well be appreciably below the upper marine limit. In general it may be said that the evidence available seems to carry the marine waters well up toward 200 feet, and possibly above that level; but it does not seem to fix the upper limit with precision.*

\section{Fossils}

Marine fossils of an Arctic type - such as Saxicava rugosa Lam. var. arctica L., Leda arctica Dawson (?), Macoma calcarea Chemnitz-were found at Birch Brook, near Seal Harbor, at an elevation of 120 feet, in blue clays overlain by stratified gravel. Similar fossils were located at Little Hunter's Brook, at an elevation of 80 feet, and at Goose Cove near sea level ( $\%$-p. 400). This signifies that the shoreline was above 120 feet in times when arctic conditions still prevailed. Certain of the stratified gravels above the blue clays are rather puzzling, and perhaps the fossiliferous clays represent not post-glacial time but some interglacial period. Altogether the evidence of fossils does not give a reliable clue to the post-glacial upper marine limit.

\section{Washed Surfaces}

There are no cliffs sufficiently persistent in their altitude and shape to be regarded as sea cliffs. If the sea was once at a higher level, it must have been only for a very short period, and the rising of the land must have been rapid. De Geer (15 and 16) in Scandinavia found a rate of emergence of half a foot per year after the vanishing of the ice. In case the emergence of New England was similarly rapid, it is easy to understand why the waves were not able to cut benches into the Mount Desert granite. The only thing the waves succeeded in doing was to remove the glacial till from the well-exposed places.

\footnotetext{
* Since the writing of this paper there has been published a report by Anters entitled : Late Quaternary Changes of Level in Maine (2-p. 320). Antevs places the upper marine limit at $\mathbf{2 4 0}$ feet in the region of Mount Desert Island, based upon Fairchild's report and his own observations on the adjacent mainland. Antevs used mostly as evidence "wash plain" of gravel and sand at higher elevations.
} 
There is not a trace of soil or even gravel on most exposed parts of the present shoreline. Every hilltop or ridge crest that was once an outstanding ledge confronting the full force of waves during a higher stand of the sea, likewise has little chance of retaining glacial till today. This does not apply to hillsides, because material of glacial origin could later be washed down from above the marine limit. Accordingly the hilltops and ridge crests on the eastern and southern parts of the Island were examined for the presence of glacial gravel and a sample was taken of the usually present soil. Where the soil is of glacial origin, its material may be different from the bedrock; where it derives from the weathering of the bedrock, it must show the same constituents. The soil samples were examined under a binocular microscope. If there were granite particles found on a well exposed hilltop composed of weak rocks, it seemed safe to assume that it was transported there by the ice. Weak rock particles on hilltops composed of granite were conclusive only if no weak rock inclusions or intrusions were present on those particular hilltops. The same principle applies to gravels, with the additional evidence that the gravel of glacial origin is likely to be better rounded than the gravel derived from recent disintegration of the bed rock.

Outside the lowlands (discussed later) the lowest well-exposed hilltop where glacial material was found was Flying Mountain, at an elevation of 270 feet. Although the summit of the hill is composed of a basic rock, there were a number of round granite pebbles on its top, even in the most exposed localities. The highest hilltop with distinctly residual soil devoid of foreign materials, is south of Bar Harbor, at an elevation of 220 feet. If one considers that the action of the waves would wash material higher than the actual sea level, the upper marine limit must be nearer the lower figure, around 220 feet, or even 240 feet.

The best illustration of washed surfaces is at Asticou Hill. This hill has a well-exposed crest which descends steplike to the sea. On the top, at 460 feet, there is a great abundance of glacial gravel, which continues

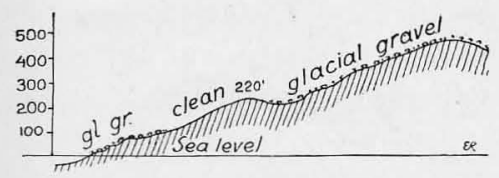

FrG. 20.-Profile of Asticou Hill. The minor hill (220 feet) is swept elean of glacial material.

down the slope to 200 feet. There is a minor hilltop at about 220 feet, and this is swept entirely clean of glacial material. At 80 feet the glacial gravel appears again. This latter was probably able to withstand removal by the waves because of the protection afforded by out- 
lying islands and possibly also because of the presence of initially thicker glacial deposits at the lower levels. Two characteristic pictures (Figs. 21 and 23) show well the difference between the clean-swept and the debriscovered surfaces.

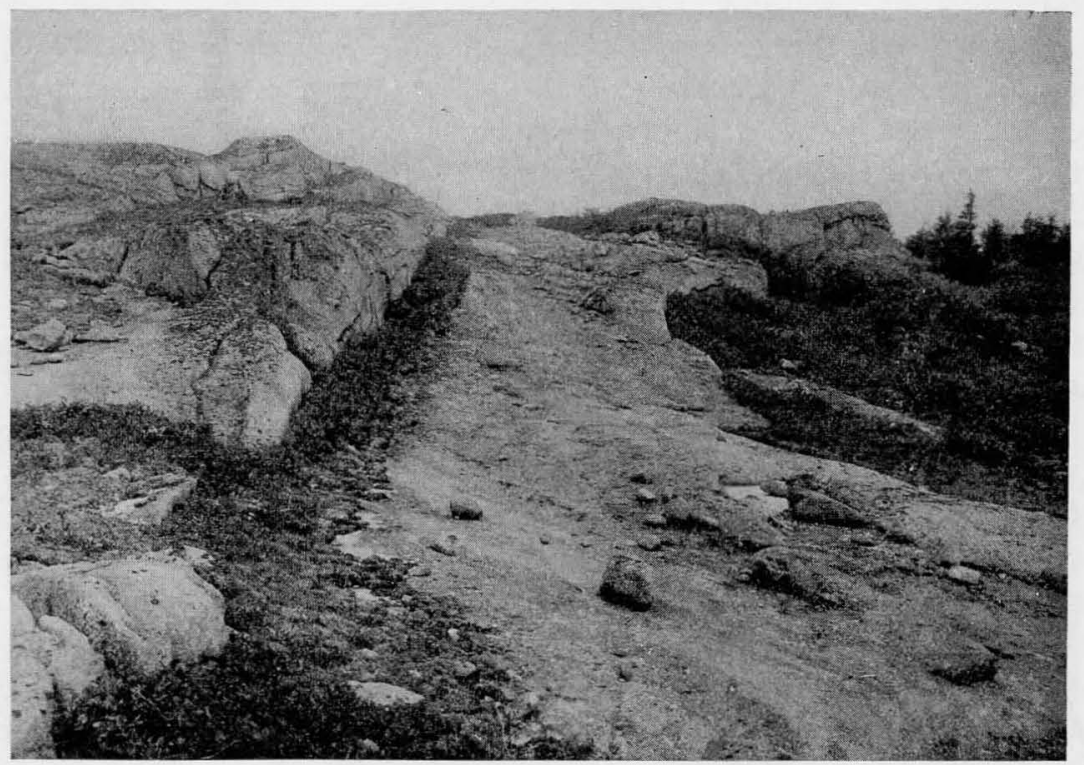

FIG. 21.-Granite surface in the mountains above the marine limit, showing glacial material.

In studying the washed surfaces certain precautions have to be taken. I was puzzled at several places by the presence, contrary to all expectations, of little round pebbles one-half inch in diameter of different material from the bedrock on well exposed ledges at very low elevations. After a visit to the little island, the Hop, the mystery was solved. This island is the favorite gathering place for sea gulls, and the little round pebbles, chiefly of white quartz, were found in an environment which left no doubt that they were the stomach stones of the gulls.

Care must also be taken to consider only those pebbles found on the exposed side of the hilltop. There is usually an accumulation of gravel on the leeward sides. On the Porcupine Islands, for example, glacial deposits persist on the northern sides at present sea level.

It is interesting to note that when Stone ( $27-p .48)$ wanted to determine the marine limit on Isle au Haut he looked for round pebbles below the marine limit. The author looked for round pebbles above 
the marine limit. Stone compared beach gravel with the less rounded glacial gravel in the sheltered places, while the author compared glacial gravel with the still more angular residual gravel of weathering on the exposed places. The method of Stone was not adaptable to Mount Desert

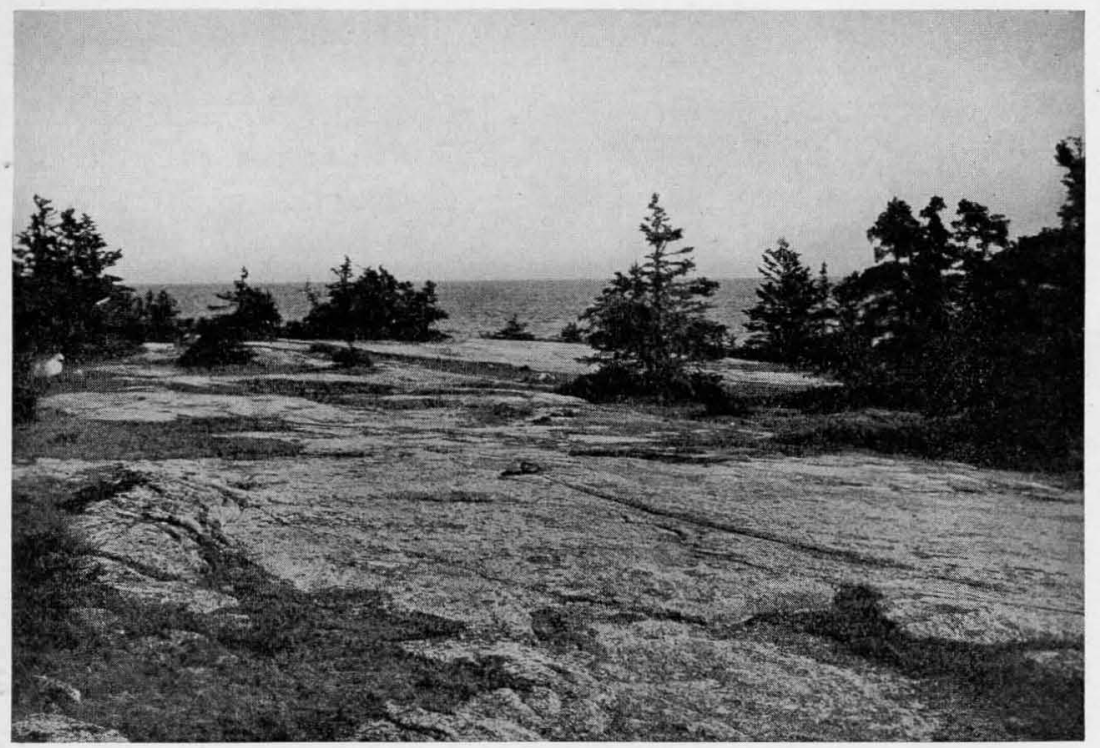

FIG. 22.-Granitic surface swept clean at lower levels, below the marine limit.

Island because most of the sheltered valleys are covered with deep soil and forests.

Although the evidence of the wave-washed cliffs is fairly clear in placing the upper marine limit at or a little above 220 feet, there are two forms of evidence which might seem to contradict this figure. First, fluvio-glacial deposits are found in the valleys down to 80 feet. Their nature and position do not admit any other interpretation than that they were formed on dry land by melting waters from the ice. This would mean that at the time of melting the Island was dry at least down to the 80 foot level. The two figures can be brought into accord if we assume that ice tongues lingered long in the valleys when the ridges were free of ice. Similar conditions now prevail in Greenland. The melting of the ice tongues at the time when the Island had arisen produced the fluvio-glacial deposits now found at lower levels than the upper marine limit. A re-advance of the ice would produce a similar effect, but there is no other evidence that this has occurred. 


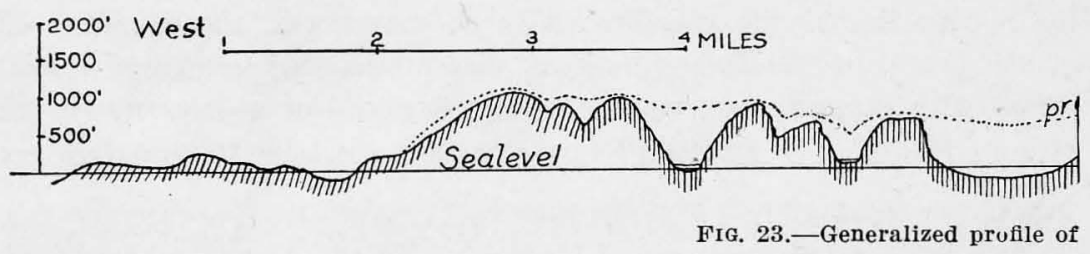

The other apparently contradictory evidence is the abundance of glacial gravel on the lowland, even on such well exposed places as, for example, the Cranberry Islands. Here we may assume that the big waves were broken on the shelving sea bottom before they reached the shore, and that the smaller waves were not able to remove the greater amount of glacial material characteristically found on the lowland areas. Only the thinly buried, well exposed hilltops adjacent to steep slopes could be swept clean of debris during the short time the rapidly rising land was exposed to wave action.

\section{FEATURES DUE TO GLACIAL EROSION}

A number of features due directly or indirectly to glacial erosion, such as roches moutonnées, plucked cliffs, giant steps and chasms, are discussed in a previous section; so also are some special features, such as the Tilted Rock and the Cadillac Cliffs, because of their direct bearing upon the question of the upper marine limit.

\section{'I'he Glacial Troughs}

The most peculiar features of the Mount Desert Mountains are the long narrow notches across the range, giving the impression that the mountains are composed of N-S trending structural ridges.

Closer examination shows that the ridges are not of structural origin, but are erosion features in a homogeneous granitic mass. The typical U-shaped form of the deep notches leaves us in no doubt about the nature of the agency which performed this erosion. These notches are typical glacial troughs, as was recognized by Shaler (25-p. 1008).

Glacial troughs are common features of local glaciation, frequently radiating out from the center of a high mountain mass. The glacial troughs of Mount Desert are strictly parallel, and have no relation to any possible local center of ice accumulation. The continental ice sheet did not commonly form troughs, but under special conditions it did so. The conditions responsible for the formation of troughs on the Island may be summarized as follows:- 


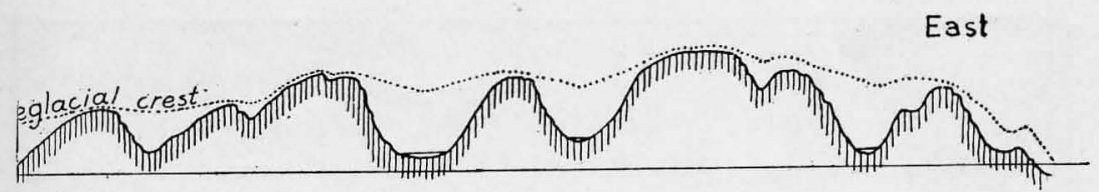

Mount Desert Island

As the continental ice sheet advanced from the north, it encountered an obstacle in the form of an elongated mountain mass with crest transverse to the ice movement. The mountain mass was at this time in the mature stage of development, with deep-cut valleys and an uneven crest. The valleys trended in a general N-S direction, transverse to the crest, but parallel to the direction of main joints and dikes. As the ice advanced from the north, it utilized the N-S valleys, spilling across the crest of the range in saddles on the divide, and deepening valleys and saddles into glacial troughs.

The most apparent thing in these troughs is their regular arrangement. There are eight deep troughs in a stretch of twelve miles, one to about every one and a half miles. It is not probable that the saddles on the pre-glacial mountain crest were placed so evenly. Initial notches developed probably in each saddle, but only those notches were able to develop fully which had a sufficient supply of ice. Where the saddles were too close to each other, the more advantageously placed ones were able to discharge most of the ice and only imperfect notches developed in the less favorable places. There are about six to eight imperfect troughs or notches on the Island, representing every stage of development.

\section{The LaKes}

Where the ice passed through the narrow troughs, its rate of motion was more rapid than elsewhere. This meant increased erosion power at the narrowest places just as streams and currents deepen their channels in narrows. As the ice vanished from the deep places, lakes were left behind. The lakes, enclosed in the narrow parts of the valleys, are the most attractive features of the Island.

During the vanishing of the ice the troughs were filled with ice tongues for a long time, and glacial debris was deposited at their southern ends. This material helped to fill the lake basins at the south, and pushed the lakes rather toward the northern part of the troughs. Artificial dams also help to keep them at their present level, but their original basins are carved directly in the bedrock. 


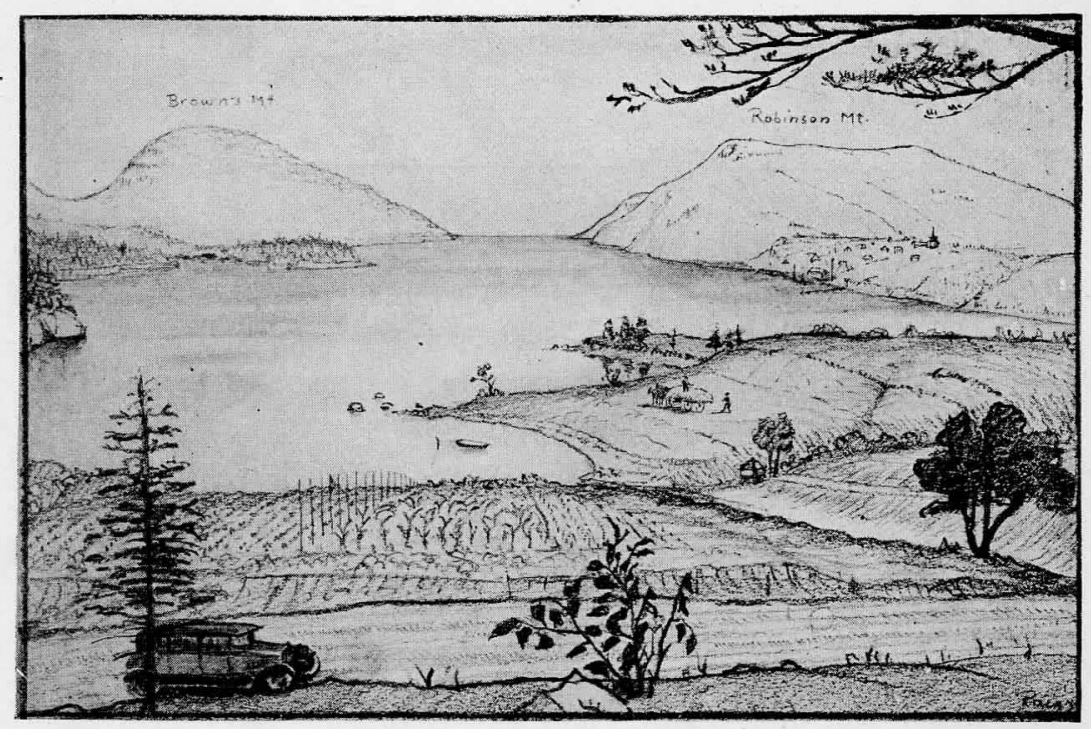

Fig. 24.- Somes Sound looking south. An example of a submerged glacial trol h, or fjord. Excepting the Hudson River gorge, Somes Sound is the only fjord of the eastern United States.

In one instance (Somes Sound) this over-deepening went so far down that the trough is at the present time submerged under sea level. Submerged glacial troughs are termed fjords. The word "submergence" does not necessarily imply actual change in the sea level. It is well known that ice streams are able to cut their channels below sea level, and that when the ice vanishes, the sea may enter the abandoned glacial channels without any change in sea level.

Somes Sound is the only true fjord (although a poorly developed one) besides the Hudson River Gorge in the eastern United States (21-p. 103). The entrance to Somes Sound is 41 feet, the middle part of it 153 feet deep. If the land should emerge about 50 feet, Somes Sound. would be transformed into a lake like those occupying the other troughs.

\section{The Asymmetry of the Mountains}

One of the most noticeable features of the ridges is that they have a smooth, western slope and a cliffed, eastern slope. This asymmetry is prevalent all over the Island, but is most characteristic in the western part, and slight in the southeastern granitic hills (see the mountain on the left side of Fig. 24). 
Asymmetry of ridges may be due to several causes, including geological structure, differences in frost action, in local glacial erosion, in insulation or in amount of vegetation, as well as to the deflective influence of the earth's rotation. On the Mount Desert range the rocks are of homogeneous granite, with no such joint structure as could produce the asymmetry noted. The effect of the earth's rotation would in many cases be the reverse of that observed. There is no great difference in frost action, insulation or vegetation on opposite slopes. As the most plausible explanation of the asymmetry we may assume the action of the ice in smoothing stoss and plucking lee slopes.

If we examine the smooth and cliffed ledges of the mountains, we find that the cliffing is not on the southern side, as one would expect if all the ice moved from north to south like that in the restricted troughs, but on the southeastern side. Certain deep glacial grooves on the mountains gave also a southeasterly direction. Where the granite is freshly uncovered, it shows a finely polished surface with well preserved striations. Unfortunately the striations are weathered off from the barren mountain tops, where only the polished surface is preserved on some of the harder quartz grains.

The direction of the glacial striations was measured at many points and a map (Fig. 25) compiled which includes results of previous measurements by Shaler (25-map). The map shows-aside from smaller irregularities - that the general directions of ice movement at the time the glacial striations were made was not the southeasterly direction of the roches moutonnées and grooves, but the nearly N-S direction of the glacial troughs. The roches moutonnées and grooves on the tops of the mountains show the direction of movement when the ice passed freely over the mountain tops. Presumably the glacial striations show the direction of movement in the last stages of glaciation.

As long as the ice was thin at the beginning of glaciation the direction of its movement was guided by the pre-glacial, nearly N-S valleys, in the place of which deep glacial troughs were carved. When the ice grew thicker and extended above the mountain tops, the direction of movement changed from a nearly N-S to a NW-SE direction. This ice movement smoothed the ascending slopes and cliffed the descending sides, thereby making the western walls of the already established N-S glacial troughs steeper than the eastern walls.

These differences in local directions do not necessarily imply an actual change in the general direction of the ice movement. It is conceivable that the general direction of ice advance during all this period was to the 


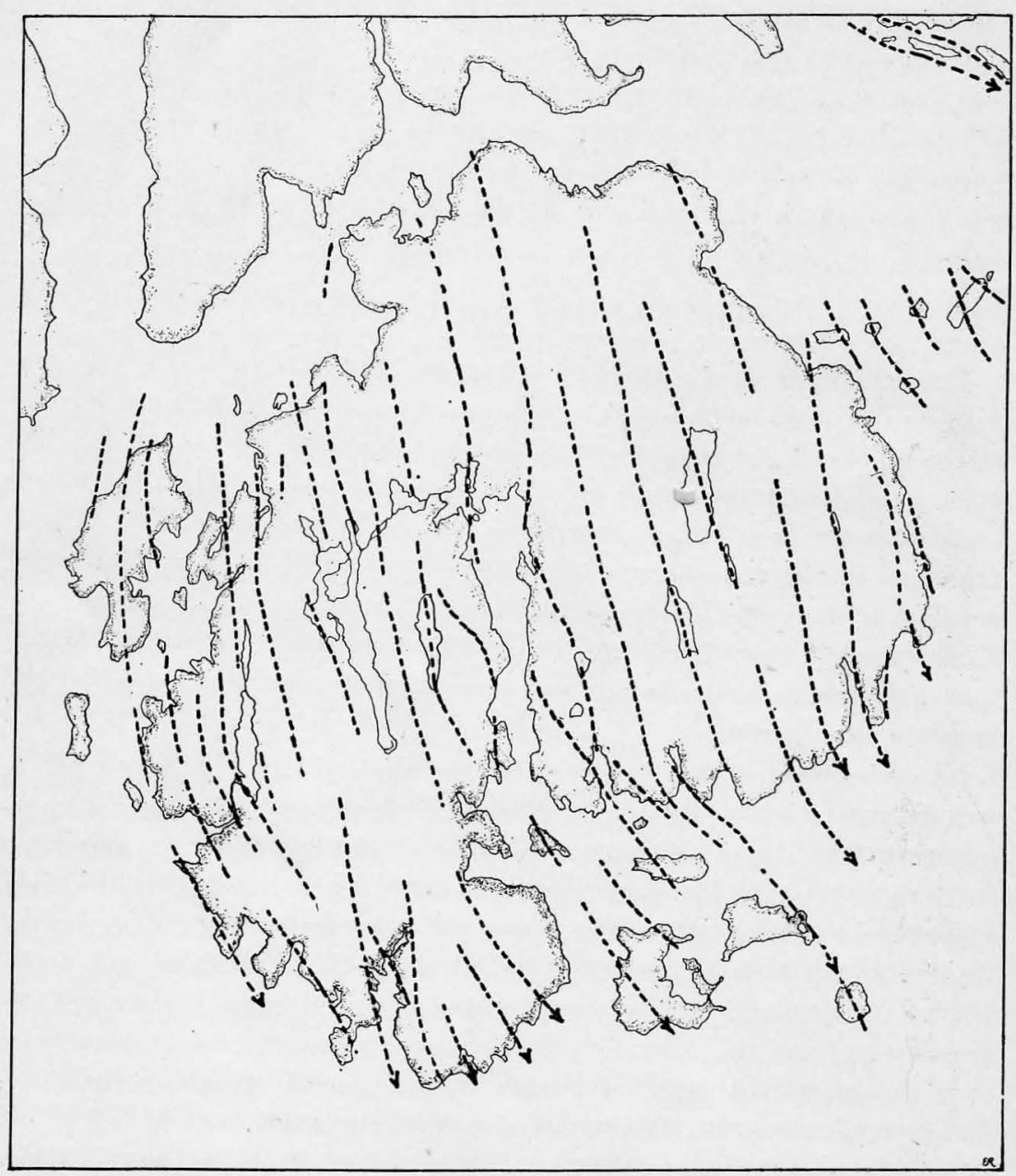

Fig. 25.-Trend of the glacial striations on Mt. Desert Island.

southeast, but that when the ice was thin, it was more influenced by the $\mathrm{N}-\mathrm{S}$ trending topography. Since in the bottoms of the glacial troughs the ice had to move in the direction of the channels at all times, there must have been during maximum glaciation a twist in the ice, a southeast direction in the upper mass of ice and a nearly $\mathrm{N}-\mathrm{S}$ direction in the bottoms of the troughs. As the bottom ice left the glacial troughs at their southern outlet, it maintained its N-S direction for a while, and this explains the absence of asymmetry in the southern granitic hills. 
The higher members of these hills, as Day Mountain, are just as asymmetrical as the northern mountains.

It is noteworthy, however, that the glacial striations do not show the NW-SE direction in the northern part of the Island, which was scratched before the ice entered the mountains. This may be interpreted as an actual change in the direction of the ice movement to a nearly N-S direction during the later stages of glaciation.

\section{The Trend of the Topography}

The ice tends to deepen and straighten the valleys which conform with its direction more than the valleys across it, and it develops a trend of the topography which can be mistaken for the structural trend. The glacial and structural trends are often superimposed one upon the other; sometimes one is stronger; sometimes the other; and sometimes, if they are equal in strength but at right angles as to direction, the topography develops a peculiar checker-board effect.

On Mount Desert Island, in the granitic mountains the structural and glacial trends coincide, but in parts of the weak rock belt the structural trend is locally transverse to the ice direction and a real checker-board topography is formed. This feature is especially marked in the southwestern part of the Island. The topographic map shows it clearly. In other parts of the Island the glacial trend is the prevailing one. The tendency of the ice to flow around the two sides of the mountain is well expressed in the topography. Note the southwest trend of the region around Bartlett Island, changing to south at Seal Cove.

\section{The Question of Local Glaciation}

The most characteristic features of local glaciation are cirques, the semi-circular hollows excavated by the headward erosion of local glaciers. North of Upper Hadlock Pond on Sargent Mountain we find two hollows which suggest this origin. Both are very crude in form and far from being typical cirques, but we should recognize the possibility that cirques were actually formed in this region.

It was probably a very long time after the climate turned cold in the beginning of the Ice Age before the continental ice sheet arrived on Mount Desert. During this time the climate of Maine may well have been colder than that of Alaska today, where even lower mountains than Sargent Mountain have glaciers.

It seems less probable that cirques originated at the time of the vanishing of the ice sheet. The cirque form appears to have been par- 
tially destroyed by later ice invasion, and the half of the northwesueru cirque is cut through by a glacial notch. From the studies of De Geer, Anters and others we judge that the vanishing of the ice sheet was a rather rapid process. The ice front retreated from a hundred to a thousand feet in a year, indicating that the climate became rapidly warmer and that it was already warm while there was still ice present.

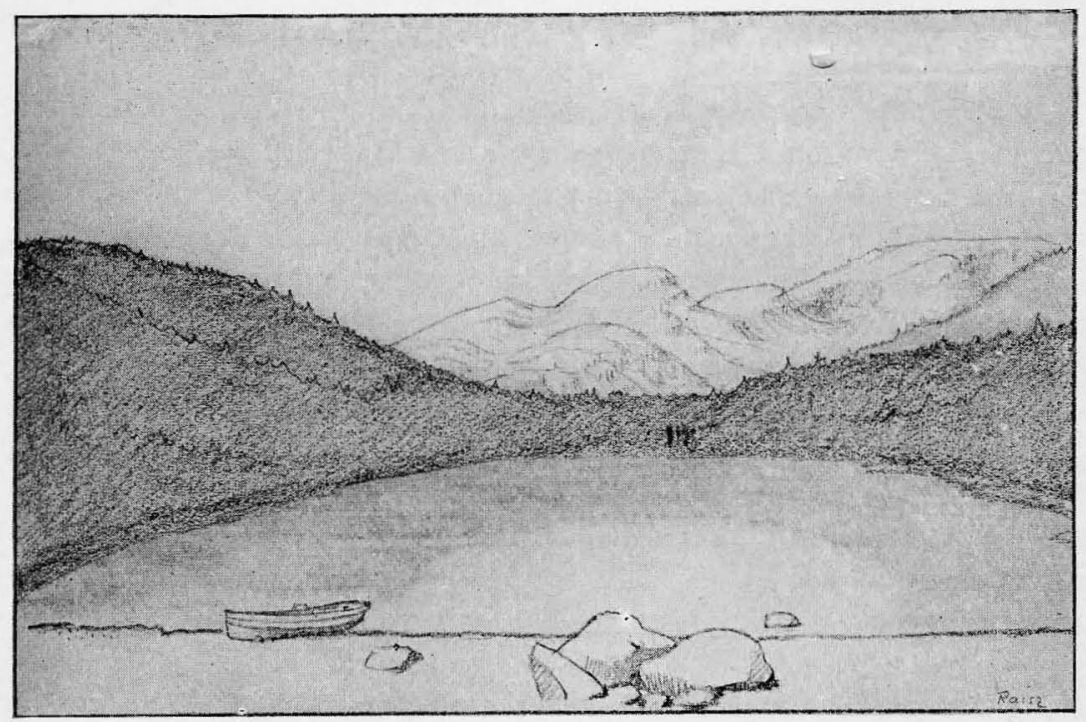

FIG. 26.-Cirques in the Sargent Mountain group.

Sargent Mountains constitute the central big group of mountains on the Island, and the most favorable place to observe cirque development. It is peculiar that no cirques are present on their northern flank. We may perhaps assume strong north winds throughout the year when the continental ice sheet was not far away. Similar strong winds are blowing outward from the continental ice sheet of Greenland, and from the Antarctic. Such a wind would blow the snow from the northern flank over the crest, and permit large masses of snow to accumulate in hollows on the southern slopes. Furthermore, daily alternation of melting and freezing may be stronger on the southern flank than on the northern, and this process is favorable for glacial plucking and for cirque carving. Thus in certain cases mountains may have better cirques on their southern exposures than on their northern. If short glaciers descended from cirques 
on Sargent Mountain, their traces could not in any case be separated from those of the later continental ice.

No other indications of cirques were observed.

\section{The Question of Multiple Glaciation}

In the central part of our continent, where deposition is the main process of glaciation, several glacial periods can be distinguished, separated by warm interglacial periods. The sequence of the glacial periods is not so clear in the northeast, where erosion was the dominating process and the terminal moraines are often under the sea.

The best evidence for a break in glaciation is a succession of deposits in wnich one member has its upper surface leached, oxidized, and perhaps eroded or covered with peat and fossils, while the next higher member consists of unaltered glacial till.

There are on Mount Desert Island a great many sand pits where the glacial beds are exposed down to bedrock. The author examined these pits with this problem of multiple glaciation in mind, but in none of them did he find any significant break in the deposition. Perhaps deeper deposits at the bottoms of certain basins would give better evidence. Unfortunately there are no satisfactory well records available on the Island. Nowhere on the Island did the author find the slightest trace of pre-glacial soil, not even in depressions and rock crevices.

Bastin (5-p. 12), investigating the neighboring districts, sought evidence of multiple glaciation in glacial striations crossing each other on the bedrock. Cross striations are rather rare on Mount Desert Island. Some were observed at Robin's Point, where they seem to be of very local occurrence. They can be explained satisfactorily as due to local and temporary variations in ice movement. As glacial striations are usually very delicate features and a new period of glaciation would be likely to destroy them, cross striations due to multiple glaciation should be of relatively rare occurrence.

\section{The Potholes}

On the southern flank of Cadillac (Green) Mountain there are a number of round holes in the granite, two to ten inches in diameter and somewhat less in depth, known as "The Potholes." The usual explanation is that boulders were rolled around by water from the melting ice and excavated holes in the bedrock, as is often done in present stream beds. 
These pot holes are much more common features of the granite than is generally thought; they were found practically everywhere in the granitic mountains in all stages of development, but usually not apparent because they are filled with soil. They are most common on the southern flank of the mountains. Apparently they have no necessary relation to the immediate local relief. They are most frequently found in flat places, but are also present on slopes.

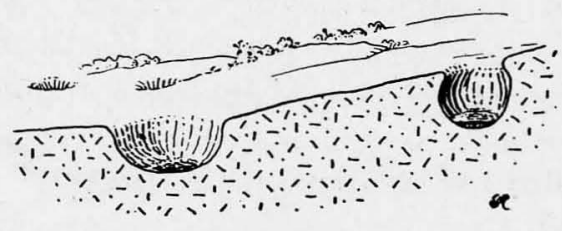

FIG. 27.-Potholes in granite.

Once by hammering at the bottom of a small pothole a piece of green epidote was recovered. Upon repeating this, in most cases the epidote was found in the smaller potholes, although this did not hold true for the larger holes.

The occurrence of epidote offers a possible clue to the origin of the potholes. Little clusters of green epidote are found scattered through the granite in many places. These weather out very readily, leaving small round holes an inch or two in diameter. Such holes are abundant in the granite and are quite commonly filled with water. Alternate melting and freezing of the water, together with chemical corrosion, has widened and deepened some of these holes, while running water, swirling sand and gravel in them, perfected their form and enlarged them. In the locality specially known as "The Potholes" there is the favorable combination of considerable amounts of water at certain seasons and much epidote scattered through the granite. That the potholes are more common on the southern flank may be explained by the more frequent alternation of freezing and melting there, while complete removal of the epidote from the greatly enlarged cavities is to be expected.

\section{The Saddle Ponds}

The glacial troughs are separated by long narrow N-S ridges. There are local saddles in the crests of these ridges, and in the middle of such a saddle there is frequently a pond. Among the most characteristic ponds of this kind are Saddle Pond on Cadillac (Green) Mountain, one north of Gorham Mountain, another south of Kebo Mountain. Where there is no pond, there is usually a marshy basin in the middle of the 
saddle. The rocks in the saddles show smooth western flanks and cliffed eastern edges, as if the ice direction had not been N-S but W-E or NW-SE. This explains the presence of the saddle ponds as minute glacial trough lakes formed under the same conditions as their big sisters in the bottom of the big N-S glacial troughs. In the saddles the ice moved from west to east because, as the ice attained its most easterly direction during the height of glaciation, it used the saddles as spillways, passing from one glacial trough to another. This W-E-moving ice transformed the initial saddles into small glacial troughs, and overdeepened these in places just as it did the big N-S glacial troughs.

\section{GLACIAL AND OTHER DEPOSITS}

\section{The Glacial Deposits of Mount Desert Island}

The glacial deposits of Mount Desert Island can be classified into three types:-

1. Fluvio-glacial deposits

2. Delta deposits

3. Unstratified till

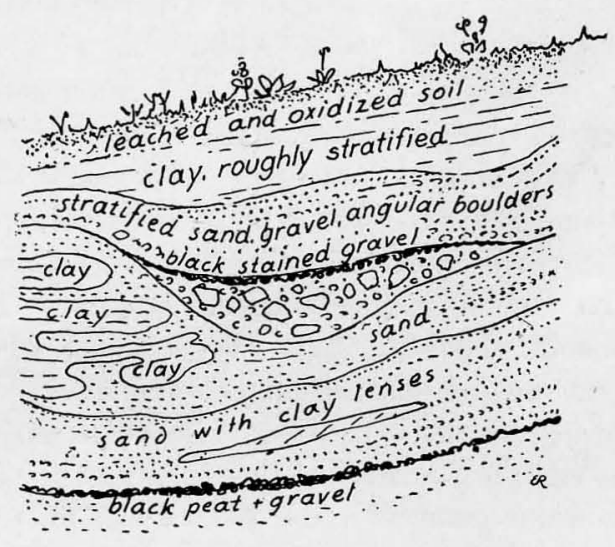

FlG. 28.-Fluvio-glacial deposits at Whales Back.

FLUVIO-GLACIAL DEPOSITS

This is the most common surface material over the Island. Its most characteristic features are a rough stratification with violent variation in size of material and dip of beds, and excessive cross-bedding, often with very steep angles. Material of this type can be found between eleva- 
tions of 80 and 500 feet. At the higher levels the cross-bedding and the variation in dip are more pronounced, at the lower levels the strata become more evenly bedded and form transition to the delta deposits. The character of the material indicates deposition by melting waters running down the slopes, excessively overloaded and varying constantly their volume and velocity.

The material varies from the finest clay to big boulders and represents the entire lithology of the country to the north. A small amount of the gravel represents material brought to the Island from a distance. Fossiliferous limestones are occasionally found, probably derived from the Silurian rocks about one hundred miles to the north. The major part of the material does not seem to have been transported more than a few miles. In the northern part of the granitic belt weak rock gravels are in excess, but in the southern part of the granitic area the weak rock gravels are much less abundant than those of granite. It seems that the ice-at least the lower part of it which carried most of the drifthardly moved at all: Naturally the most violent variation of materials is on slopes high up in the mountains; during transportation the material underwent sorting; therefore we find the rougher stratification of the higher slopes becoming more regular and more horizontal nearer sea level.

\section{THE DELTA DEPCSITS}

In several places on the Island, especially in sheltered valleys, we find exposures of finely laminated and well sorted sands forming strictly parallel laminae inclined $20^{\circ}-25^{\circ}$. This series of beds is sometimes truncated by a less perfectly stratified horizontal series, often containing much coarse gravel and even cobblestones. Such type of deposition is characteristic of delta deposits. As a river bearing glacial debris from the melting ice entered the sea, the current was checked and it dropped its load to build a gradually expanding delta. The angle at which the material came to rest on the front of the delta was the angle of natural repose, under sea water about $25^{\circ}$; successive additions to the delta front formed the "foreset" beds. As the load and velocity of the rivers varied, the laminae became finer or coarser, while still coarser material was left stranded on the delta surface to form the horizontal "topset" beds.

Complications arose through the gradual emergence of the land. The delta deposits, which were formed a few feet below low tide level, became exposed to the force of the waves. Only in sheltered bays were 
they able to survive and emerge above sea level. With this emergence the delta moved seaward and new delta deposits were laid down on top of the outer beds of the old delta.

\section{THE UNSTRATIFIED TILL}

It is especially in the bottoms of the deeper valleys that we find unstratified till, composed of debris of all sizes, ranging from clay to big boulders. These deposits are well exposed in the open coves of the south shore, where they are cut back by the waves. Their thickness is considerable, up to 30 feet or more. Probably enough debris was removed from hillsides and valley bottoms and dragged along the bottom of the ice to form the ground moraine represented by these deposits, which are unstratified because dropped by the melting ice without the sorting action of water.

\section{Other Deposits}

THE BLUE CLAY

In some localities, as in the smaller brooks on the south shore, a fossiliferous blue clay is found. This clay is extremely fine and plastic, blue in color, with streaks of black organic matter locally present. It is so soft that I was able to push into it by hand a pipe nine feet long. The material seems to be quite homogeneous, showing no variation in color or texture.

The blue clay evidently represents deposition in very quiet water where no disturbances took place. Well preserved barnacles indicate that it could not have been very far from the shoreline. The clay is found usually in the shorter valleys, such as Birch Brook, east of Seal Harbor and Little Hunter's Brook. It is covered with stratified gravels, some of which are very evenly graded, as at Sargent Brook, while others are similar to the fluvio-glacial deposits, as in Birch Brook. The height of the blue clay ranges from 80 to 120 feet above sea level.

The fossil content of the blue clay shows that the sea stood at the time of its deposition more than 120 feet above the present level, and that there were subarctic conditions at that time. Clay in such purity indicates that at the time of deposition no glacial debris was baing actively deposited in the vicinity.

\section{THE SURFACE DRIFT}

Over the entire Island the uppermost layer of stratified deposits differs from the lower part. Usually it is devoid of stratification; it is more brownish in color and generally of a coarser material than the deposits 
below. The transition to the stratified drift is rather abrupt, and is usually marked by a fine layer of clay. The uppermost few inches consist of gravel and boulders, with black soil. On examination with the microscope the unstratified superficial material and the stratified material seem to be much alike; the only difference is that the sand grains of the surface drift are coated with a very fine layer of clay, while the stratified sand is relatively clean. After washing, the two materials appear almost identical. Closer observation of sand pits disclosed that there is often in the superficial drift a vestige of stratification; and the fine clay layer which usually separates the two kinds of material is not persistent-the dividing line jumps from one fine clay layer to another.

The foregoing facts are interpreted to mean that the superficial unstratified drift is an alteration product of the stratified drift. Surface creep and other movements in the superficial zone have largely destroyed the stratification and mixed the thin clay layers with the sand. Leaching of this surface zone ceases where the descending waters encountered an undisturbed clay seam and were by it deflected laterally.

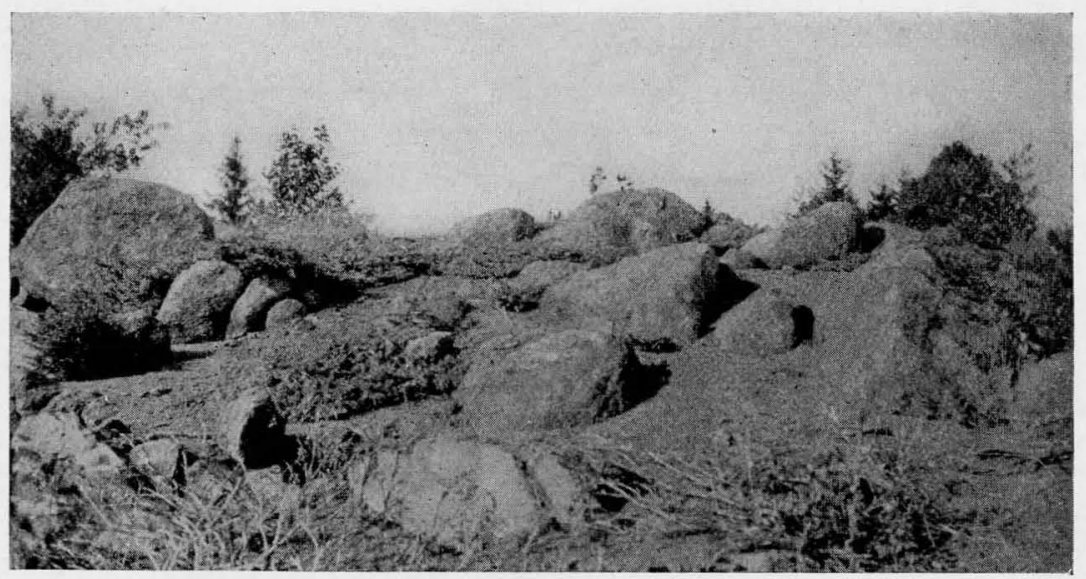

FIG. 29.-Residual soil on Robins Hill.

POST-GLACIAL SOIL OF WEATHERING

Robins Hill is composed of black granite (diorite), which decomposes readily. The granite boulders shown in Fig. 29 are in place, or but slightly moved. The soil between these boulders is a granular mass of angular fragments from the minerals which composed the black granite, and the thickness amounts to several feet. As mentioned 
above, all the granitic mountains and hills have a forest covering except the tops of the ridges. This forest grows in a scanty soil, most of which is not glacial soil as might be expected, but residual soil due to weathering.

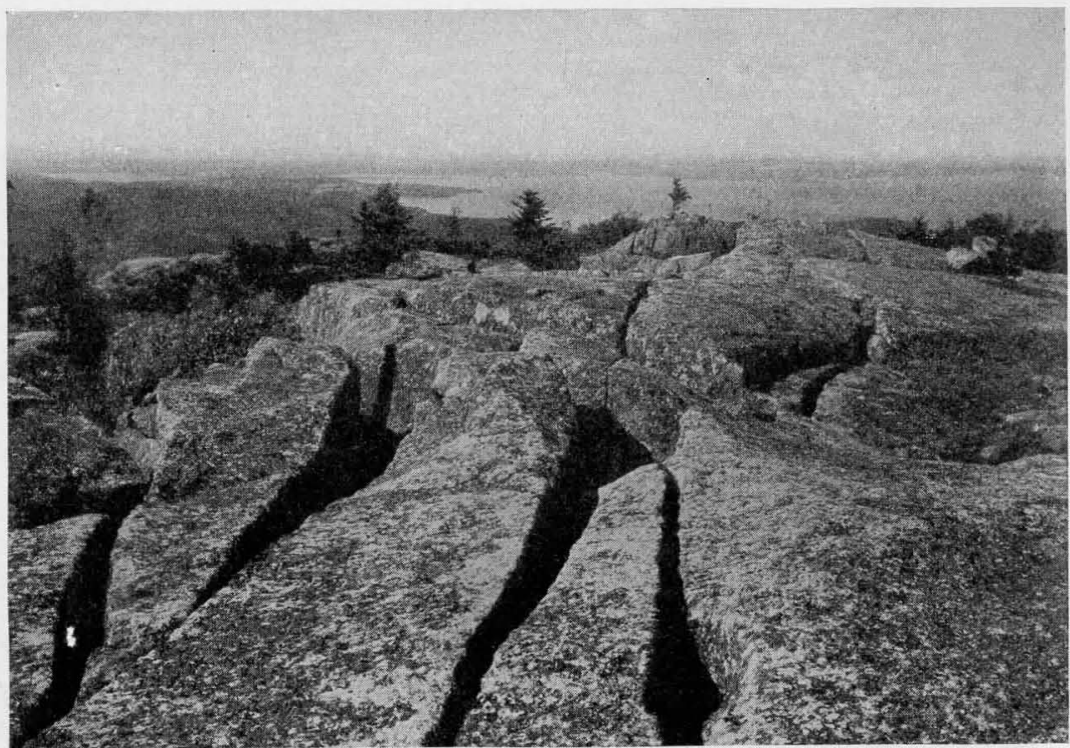

FIa. 30.-Cracks in the granite enlarged by weathering.

The formations of the weak rock belt weather still more readily. The rocks on the surface disintegrate into angular boulders, and the cracks between them become filled with a reddish soil.

\section{TALUS SLOPES}

After the vanishing of the ice, the over-steepened walls of the glacial troughs could not long stand in their unstable position, and much of their material tumbled down, forming talus slopes composed of big boulders. Some of these blocks are of great size, as the Giant and Bridge on the southern slope of Jordan Mountain. Another good talus of large blocks is found above the bridle path on the Rockefeller estate on Bar Hill. Many of the rocks show glacial striations on one side, proving their post-glacial origin.

\section{ERRATICS}

All over the Island there are big boulders of foreign material, strangers to these mountains. These erratics or ice-carried boulders sometimes 
are of enormous size; one on the estate of Professor Lnquer on Sols Cliff measures about twenty feet in greatest diameter, and forms a giant monument of the icy past.

\section{SHORELINE DEVELOPMENT'}

\section{Shoreline of Submergence}

The shoreline of the Island belongs to the class of shorelines of submergence. This term does not imply that submergence was the only movement nor even that it was the latest movement; it means only that the forms of a dissected land dominate at the shoreline and not the forms of a smooth sea bottom. Investigations of the sequence of changes in the past are discussed in a previous section. In the following paragraphs the features of the present shoreline are discussed.

The shoreline of the Island may be subdivided into three types: one developed on granite; another on weak rock; and a third on the contact zone between the two types of rock. All three situations show different shore forms, depending on the initial character of the shore (steep or flat), the direction of dominant wave attack, and amount of glacial till or other blanketing deposits.

\section{THE SHORELINE ON GRANITE}

Most of the shoreline of the Island is within the weak rock belt. There are only two places where the shoreline is on granite, but both show very interesting features.

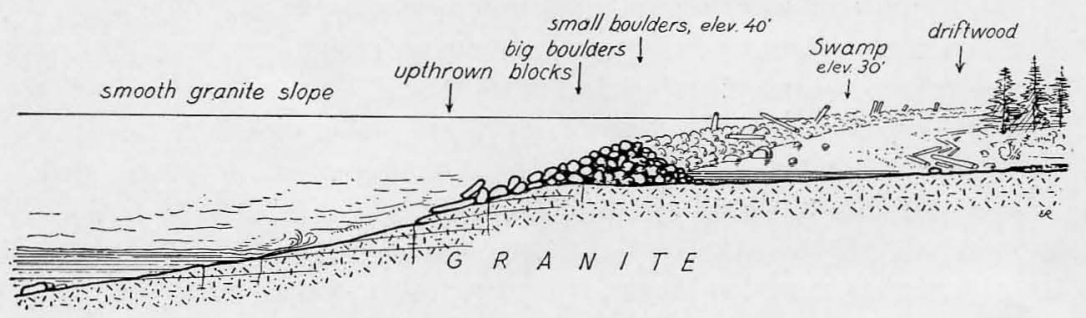

FIG. 31.-The Baker Island type of shoreline. This shoreline consists of a relatively gentle slope of granite crowned by a dam formed of uphurled boulders. Back of this dam the inland waters are ponded.

(a) The Baker Island Type of Shoreline.-The most peculiar shoreline is developed on Baker Island, a round little island about one mile across, south of Mount Desert, where it is fully exposed to the Atlantic waves. At this place, where we might expect to have the highest cliffs, we find a smooth, gently sloping rocky platform, which allows the waves 
to ascend high up the shore. Here the force of the waves is broken by a dam of giant blocks of granite, reaching about forty feet above sea level. This boulder dam ponds the inland waters of the island and a string of swamps is formed behind it.

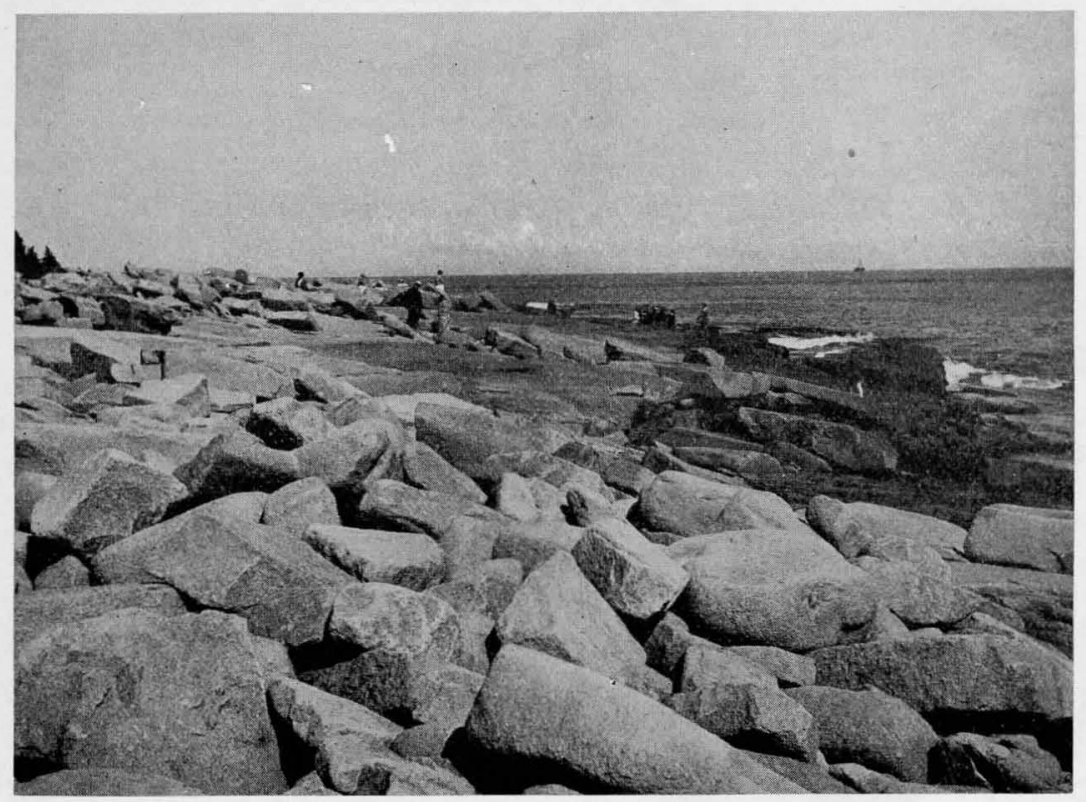

FIG. 32.-The southern shore of Baker Island. Note the gentle seaward slope of granite, and the heaped-up boulders above.

Bascom and Johnson attribute the development of the smooth slope of granite primarily to the direction of the joint planes, which here dip at a low angle toward the ocean. Such a smooth sloping shore is very characteristic of many outlying islands composed of granite. These slopes occur not only on the most exposed side, but on three sides or even all around the islands, as shown in Fig. 33. This would imply that the joint

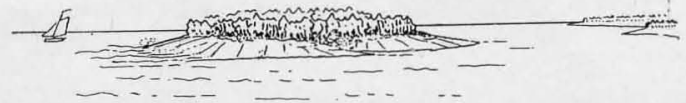

FIG. 33.- Small granitic island in Penobscot Bay. Islands like this have smooth, gently sloping, rocky shore on all sides and no cliffs, probably the result of exfoliation.

planes dip everywhere slightly towards the sea, and hence that the direction of jointing must change on each side of the island. 
This was at first thought to be incredible, and the assumption was made that the granite has hidden joint planes in nearly every direction, the waves working along those planes which suit best their profile of level. Professor Johnson called the author's attention to the fact that the change of dip of the joint planes so as to give seaward-sloping fractures all about an island is not only credible but a phenomenon to be expected where hills are partly submerged.

When granite which crystallized under very great pressure reaches the surface through erosion of overlying beds, the compression is released and tension cracks develop which are roughly parallel with the surface, as has been described for the exfoliation domes of the High Sierras. Scaling-off along this crack may be the main cause of exfoliation. It seems possible that all of the curved subhorizontal joint planes on the island are of this origin. As they developed parallel to the surfaces of the rounded hills, they slope everywhere toward the sea, thereby producing smooth, gently sloping shores.

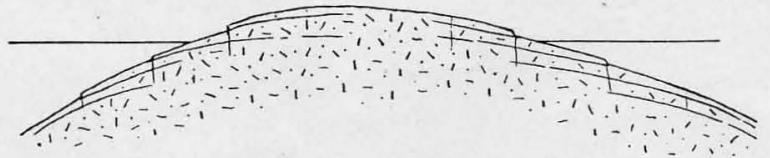

Fig. 34.-Exfoliation fractures on a partially submerged granitic hill.

The small vertical cliffs developed by cross fractures passing from one exfoliation plane to the next are favorable points of attack for the waves, and huge blocks of granite are rifted loose and hurled up on the shore. The sizes of the upturned blocks are sometimes astonishing. Blocks from 10 to 20 feet long, and 2 or 3 feet thick, lifted by the waves, are not uncommon. The boulders of larger size are at the base of the natural dam or beach ridge, and the size decreases near the top and on the landward slope; there the boulders are about the size of a man's head and well rounded. It is surprising that this dam is developed also on the north-facing corner of Baker Island, where the waves have only a few miles' fetch. The extraordinary power of the northerly waves will be referred to later.

It is worthy of note that similar boulder dams were not found inland at higher elevations. Probably the sea never stood for any considerable time at any higher level in post-glacial time.

The Baker Island shoreline illustrates the features that occur where strong waves attack initially low land of granite. 
(b) The Thunder Hole Type of Shoreline.-Where the waves attack vertically jointed granite with an originally steep surface slope, the result is a shoreline which might be called a Thunder Hole shoreline, after the chasm of this name on Mount Desert.

The granite is usually parted by joint planes into large rectangular blocks. The vertical planes are several feet apart and are very persistent in direction. The nearly horizontal joint planes, described above, are close together, but inclined slightly in varying directions and are usually curved. Because of the large size of the granite blocks, small waves leave them practically unaffected, and only the biggest storm waves are able to attack them effectively. If the original slope is steep, even storm waves are unable to hurl up blocks as on the Baker Island type of shoreline. The strong waves remove blocks along the parallel, well developed vertical joints, especially along the S-SE set of master joints, which on the southern shore is nearly perpendicular to the shoreline. The separated blocks are carried downward on the submarine slope and in place of the block a hole is left into which the water is crowded during a storm and has no other escape than upwards. These upwardforced waves have a tremendous impact, rift up further blocks at the base of the hole, and finally develop a chasm with straight vertical side walls called Thunder Holes.

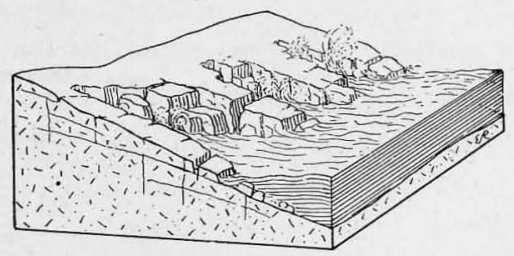

Fig. 35.-A Thunder Hole shoreline consists of a series of marine chasms separated by ridges, the seaward ends of which are but slightly cliffed.

It is a wonderful sight to stand above the rocky slopes and watch these deep chasms into which, at every swell, the waters roar with a voice like thunder. Because of this impressive view, the granitic type of shoreline looks extremely rugged and cliffed. But when we look upon the profile sideways from a distance, and do not see the thunder holesonly the profile of the ridges between them-we note that on this profile very slight cliffing is discernible. It is surprising to find glacial striations on these spurs nearly down to sea level.

When the granitic shoreline is not exposed to full-sized waves, there is hardly any noticeable effect. The glacial till is stripped off, but the rocks show glacial striations, the waterline is marked by a strip of barnacles, and the rocks pass unaffected below sea level. 


\section{THE WEAK ROCK SHORELINE}

The effect of waves on the weak rocks is very different. Although the weak rocks are composed of a great variety of formations, their behavior under wave attack is rather uniform. They all have one property in common: the rocks have an intricate network of joints, and the small fragments break off easily.

On this much-jointed mass even the effect of small waves is noticeable. The retreat of the shoreline is much more rapid than that bordering the granite. The wearing back of the entire mass results in a rather straight vertical cliff, the height of which depends upon the steepness of the original slope. When the shore is sufficiently high, there may be a notch or sea cave at sea level, and a straight, sometimes overhanging cliff above. The cliffs reach to a height such as is found nowhere else along the Atlantic coast of the United States.

It is rather surprising that on the northern shore of the Island, where the waves have a fetch of only a few miles, we find some of the highest cliffs, arches and sea caves.

The assumption that the sea once stood for a considerable time at a higher level to form the upper part of the cliffs is not probable. The rate of the emergence seems to have been relatively rapid, as is shown elsewhere in this report. It is tentatively suggested that following the glacial time, the northwest blizzards were much more violent than at the present time. The great anti-cyclone formed over the ice cap at the time when the ice was somewhat north of our latitude must have produced northwest blizzards of unparalleled fury.

\section{THE SHORELINE OF THE CONTACT ZONE}

Nowhere on the Island is the difference in behavior of the granite and weak rock under wave attack better exhibited than along the southeastern shore formed along the contact between these two types of rocks. As the molten granitic mass forced its way into the older rocks, it penetrated along fractures and eventually incorporated and partially fused large masses of the older series. This irregular contact zone of the granite and weak rock formations is usually several hundred feet wide.

The original landform against which the sea came to rest was an indented surface, consisting of spurs with glacial troughs between them perpendicular to the shoreline. The slopes at the southern ends of the spurs were initially steep and cliffed. As the sea attacked these cliffs, it found the confused mass of the contact zone. At first it worked against the outer portions, in which the weak rocks predominated. In these 


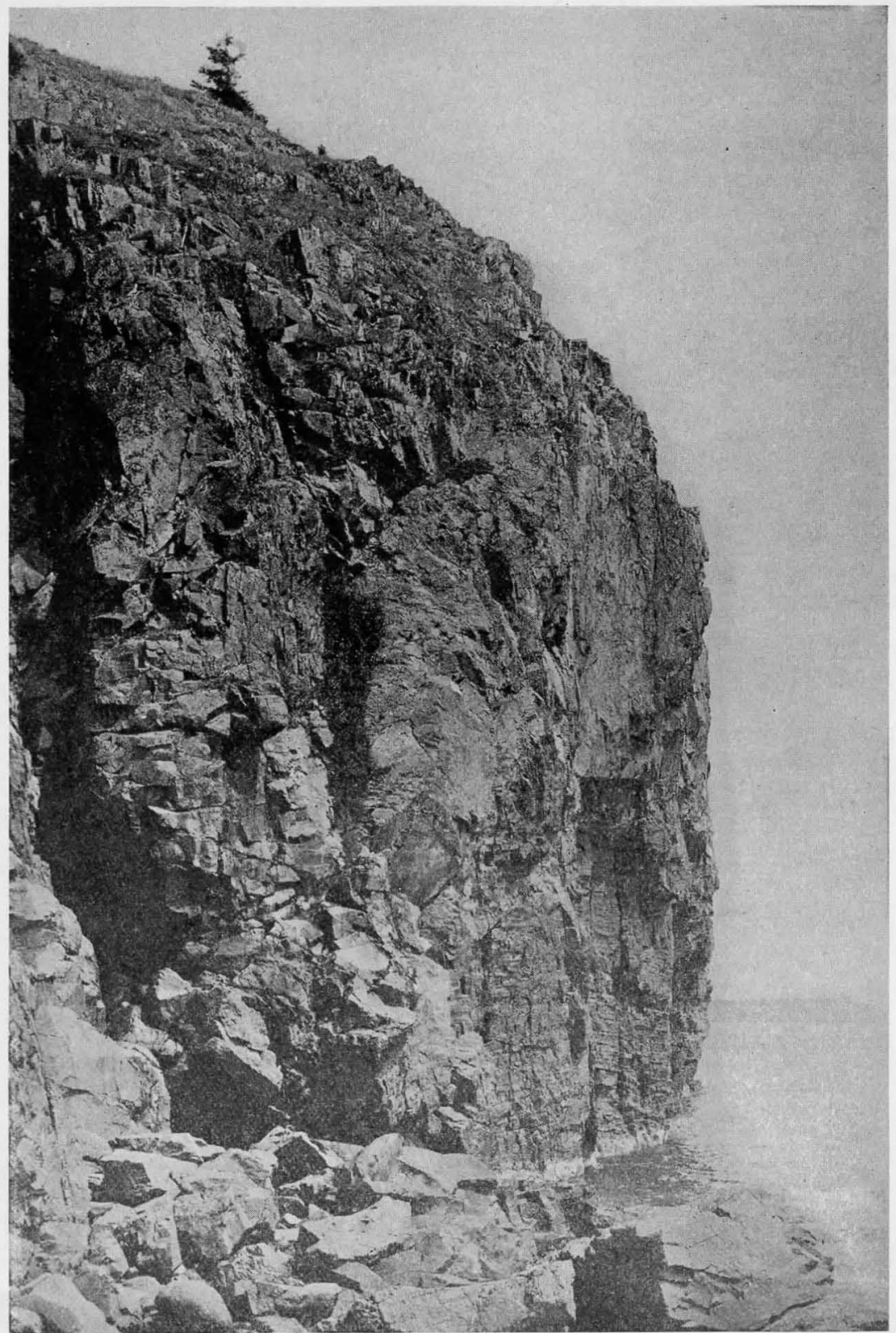

Fig. 36. - Great Head, one of the highest headlands of the eastern United States. 


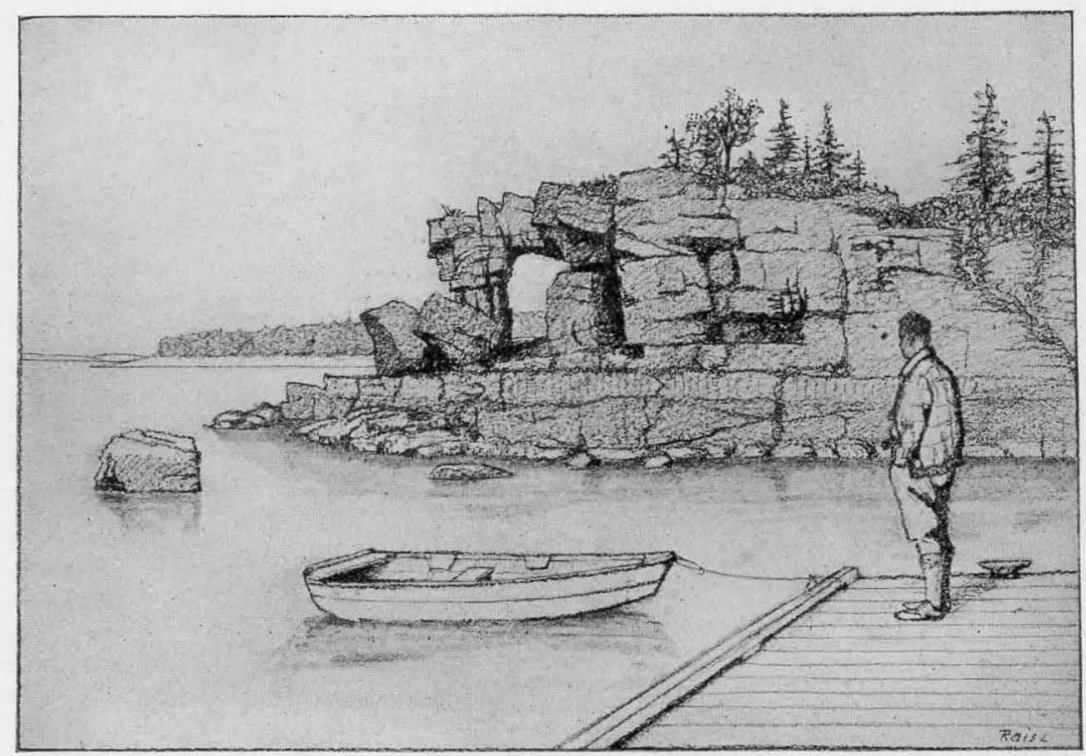

FIG. 37.-A marine arch near Salisbury Cove.

weak rocks high marine cliffs developed; as the cliffs receded, they penetrated more and more into the granite. The present cliffs are at the place where the predominating rock is granite, but the unusual height of the cliffs is inherited from the weak rock belt.

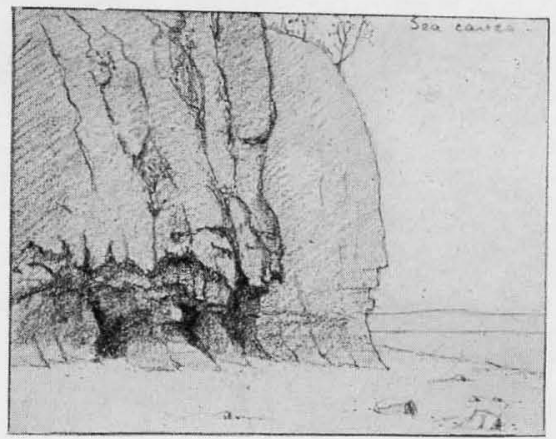

FIG. 38.-The Ovens. Marine caves and arches in weak rocks on the northern shore.

Some minor examples illustrate the different behavior of the granite and the weak rocks under wave attack. Figure 39 shows a portion of the shoreline east of Sandy Beach (Newport Cove). The outer shoreline is developed on steep slopes of granite, but the waves have cut through 
its contact zone in one place and carved a sea cave into the weak rock series (locally a part of the granite is here south of a mass of the weak rocks), the cliffs overhanging above. The form of the small rock mass in the foreground of Fig. 39 is noteworthy. It is composed of granite on
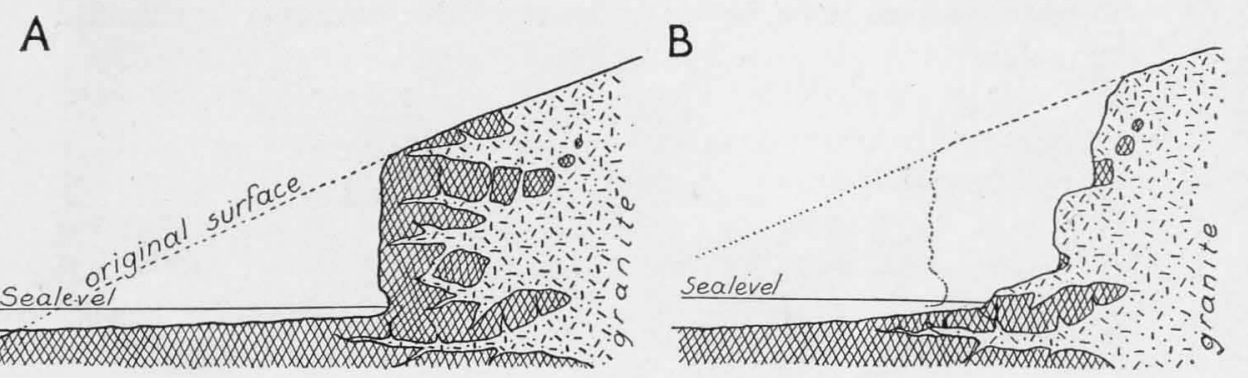

FIG. 39.-Inherited cliffs of the contact zone shoreline.

the seaward side and of weak rock on the landward side. The granitic side, although fully exposed to the waves, is little affected, but the weak rock portion-although it is on the protected side and gets only the rehound waves - shows sharp cliffing. Hundreds of cases illustrate similar behavior of these contrasted rock types.

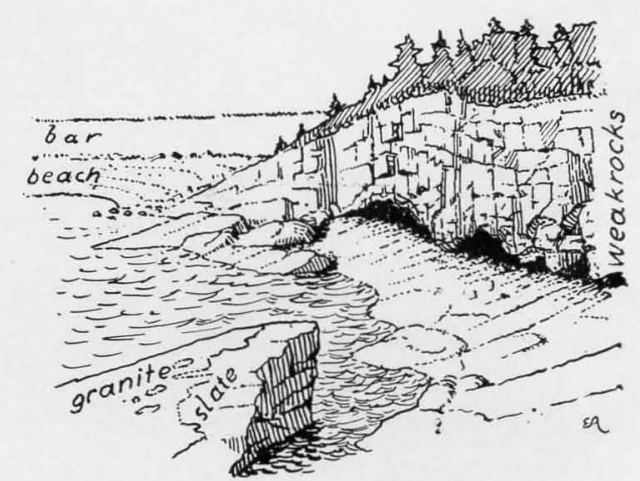

Fig. 40.-Caves near Sandy Beach (Newport Cove) in cliffed weak rocks near granite contact.

(a) The Coves.-The physiographic significance of the coves is in their bearing on the problem of post-glacial submergence. If the land once stood higher during post-glacial time, streams may have cut postglacial notches in the bottoms of the ice-carved valleys. If the land was later submerged, the valleys would be transformed into coves, and the post-glacial notches - if undisturbed-would pass under sea level. 
Figure 41 shows the different types of coves which would have developed by 1) a submerged river valley; 2) an ice-carved valley partly occupied by the sea without post-glacial emergence or development of a notch; 3) submerged glacial valley in which a post-glacial notch was cut when the land stood higher. The two latter cases may be modified
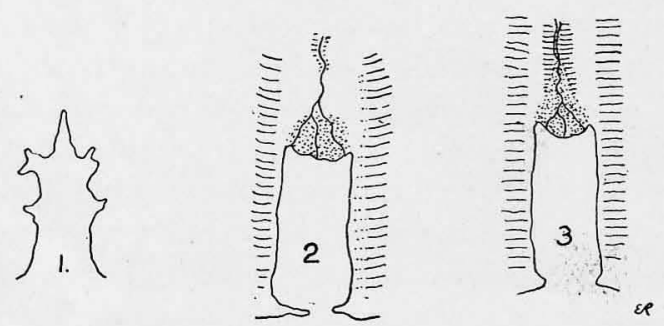

FIG. 41.-The form of coves: 1) submerged river valley; 2) glaciated valley now partially occupied by sea ; 3) glacial valley with a post-glacial notch, indicating former higher stand of the land.

by stream deposition. Only deep sheltered coves can be taken into account, because open coves are subject to modification by wave attack. Of course, slight incisions made by streams due to tidal variations or to seasonal changes of stream volume and channel size should not be mistaken for post-glacial notches.

In most of the deep coves, especially in Otter Creek Bay, the incision of the stream flowing into the cove is much deeper than the tidal range or seasonal changes in streams would account for. Apparently we find in this fact support for the view that sometime in the post-glacial period the land stood higher than at the present time, and that the last movement was a slight submergence. The drowned river pattern at the northern end of Somes Sound and at Marshall Brook also support this view, which accords with conclusions revealed by other students of the region.

(b) Beaches, Bars and Tombolos.-From the cutting back of the cliffs and the stripping off of the glacial debris there was such an amount of material available that it could not be entirely carried off by the waves; some of it was deposited along the shore.

The most common features of marine deposition on Mount Desert Island are the fine bayhead beaches. At the head of nearly every cove we find these smooth, regularly curved gravel banks. The material varies in size, but is mostly composed of gravel; pure sand beaches are exceptional. If the supply of material is abundant, and the cove is not too much exposed to wave attack, the beach "progrades" or grows out toward 
the sea. This is commonly the case on the Island, but where the material is scanty and the waves have easy access to it, we have "retrograding" beaches, such as Little Hunter's Beach, with a freshly cut cliff at head of the Bay.

(c) Spits and Bars.-These are formed when an oversupply of material, carried by the longshore currents, is built out into the water from the sides of the headlands in the form of a narrow sand-ridge.

Spits occur where the sand-ridge does not reach the next headland but terminates in open water. The best examples are between the two Cranberry Islands, where spits start out from both of the islands, but fail to join, leaving Cranberry Harbor still somewhat open.

Bars are formed when the sand-ridge almost or entirely closes the bay. They are usually concave toward the sea and often have an opening for the inflow and outflow of tidal waters. According to the width and depth of the bay, the nature of the longshore current, the available load,

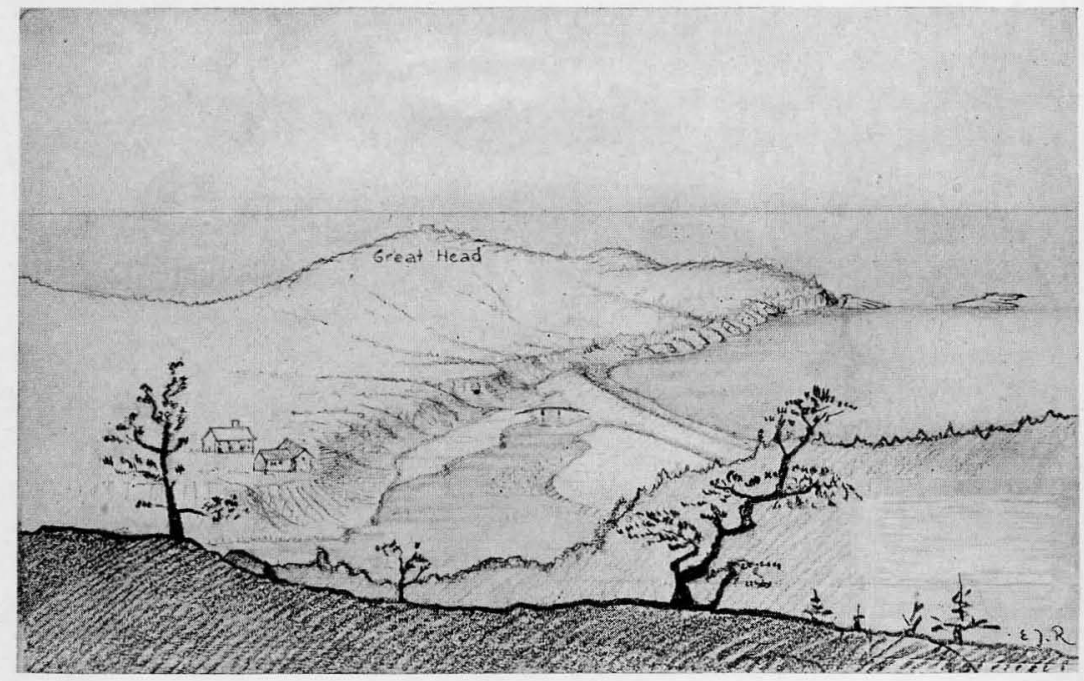

FIG. 42.- Sandy Beach (Newport Cove) from the Beehive.

the bar may be at the mouth of the bay (as on Long Pond*); in the middle of the bay (as in the submarine bar in Otter Creek Bay); or it may be driven back into the bays so deep that it actually reaches the bayheads, as in Hunter's Beach and Sandy Beach (Newport Cove), where the rivers behind the bars are ponded, forming fresh water pools (Fig. $42)$. Behind the bars stream deposition helps to fill up the coves.

* The pond here referred to is the lesser Long Pond at Seal Harbor, not the Long Pond mentioned elsewhere as among the major lakes of the Island. 
(d) Cuspate Bars and Tombolos.-When a bar forms a $V$ enclosing a lagoon or marsh, it is called a cuspate bar. The best example of a cuspate bar is at Rice Point, on Sutton Island. When a bar connects an island with the mainland or with another island, it is called a tombolo, or island-tying bar. Tombolos are very common about Mount Desert Island. The name "Bar Harbor" is derived from a tombolo which connects Bar Island with the mainland. Nearly all the tombolos are flooded at high tide. A complex arrangement of bars, spits and tombolos may be noted around the Cranberry Islands.

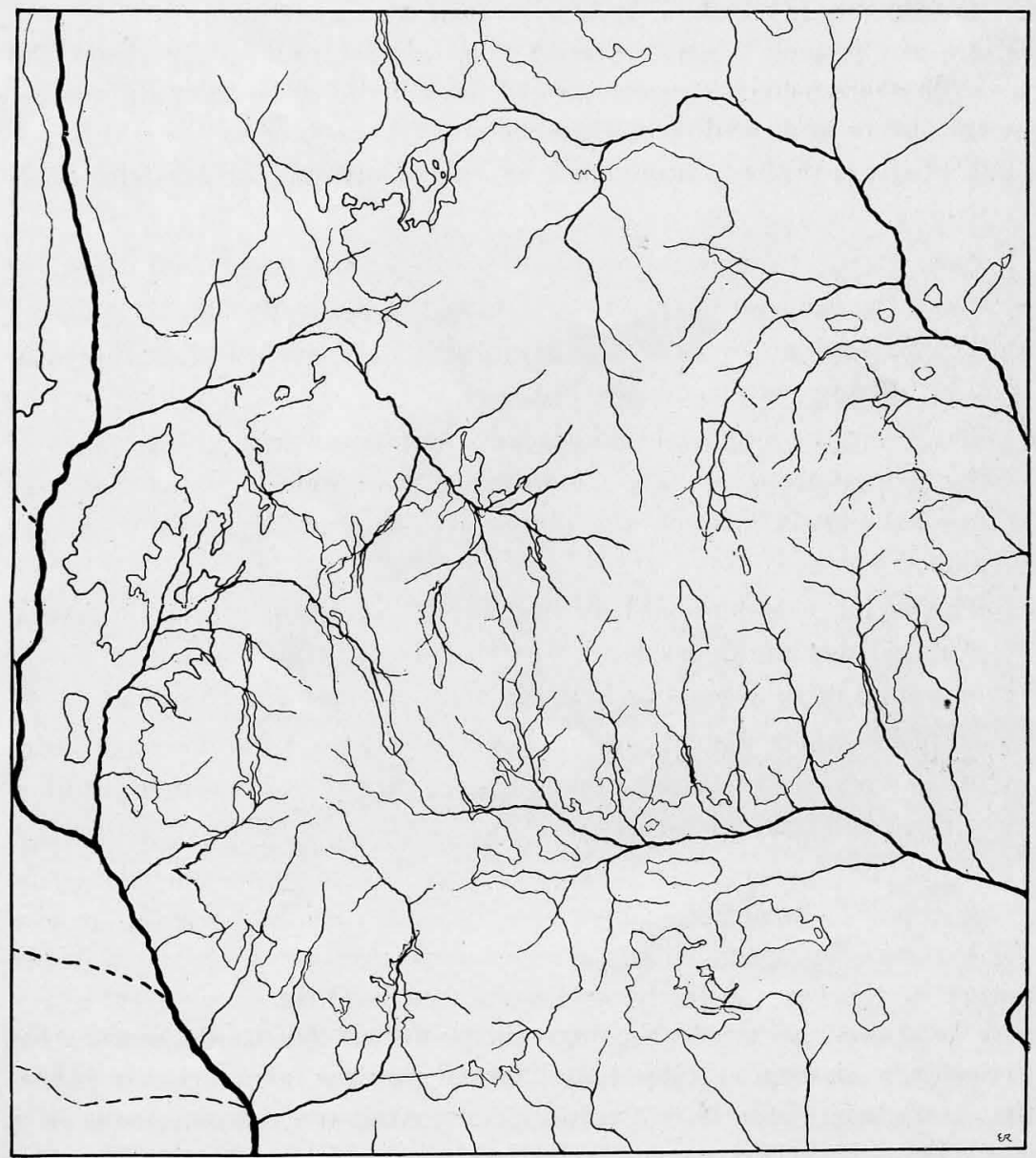

FIG. 43.-The supposed pre-glacial drainage of Mount Desert Island. 


\section{THE DRAINAGE HISTORY}

For better understanding of the drainage problems on Mount Desert Island, the writer has attempted to reconstruct the river system of the Island as it appeared before the Ice Age. Map Fig. 43 shows the result of this study.

The map is based on the following assumptions:

1) The pre-glacial drainage was somewhat dendritic in pattern, but due to the structures in the granite had a noticeable N-S trend. It was in a mature stage of development.

2) The ice deepened and straightened the N-S valleys; the E-W valleys were in general unaffected, except that their north sides were made steeper and the southern walls smoothed.

3) The ice cut through the mountains deep glacial troughs, thereby establishing new drainage routes.

4) Each of the troughs represents a saddle in the pre-glacial crest, between the head-waters of north-flowing and south-flowing streams.

5) The pre-glacial crests of the mountains were pushed slightly southward during glaciation (see Fig. 44).

6) The deepest pre-glacial saddles were not necessarily at the place of the deepest troughs. The ice deepened most those troughs that were not too closely spaced; the others are represented only by smaller glacial notches.

7) The region was depressed during the last stages of glaciation several hundred feet under sea level. At the present time the region is still in a state of submergence, and the main streams are drowned.

8) In places where glacial erosion was most vigorous due to convergence of ice streams or to other causes, the ice carved basins which are filled with lakes at the present time.

9) Accumulation of glacial debris blocked certain pre-glacial stream channels to form lakes or swamps or even displaced streams to new courses.

A comparison of maps, one showing the pre-glacial drainage, the other the present drainage, discloses the marked changes introduced by glaciation and change of level. The pre-glacial drainage was well organized, while the present drainage shows disarrangement and abnormal conditions throughout. 


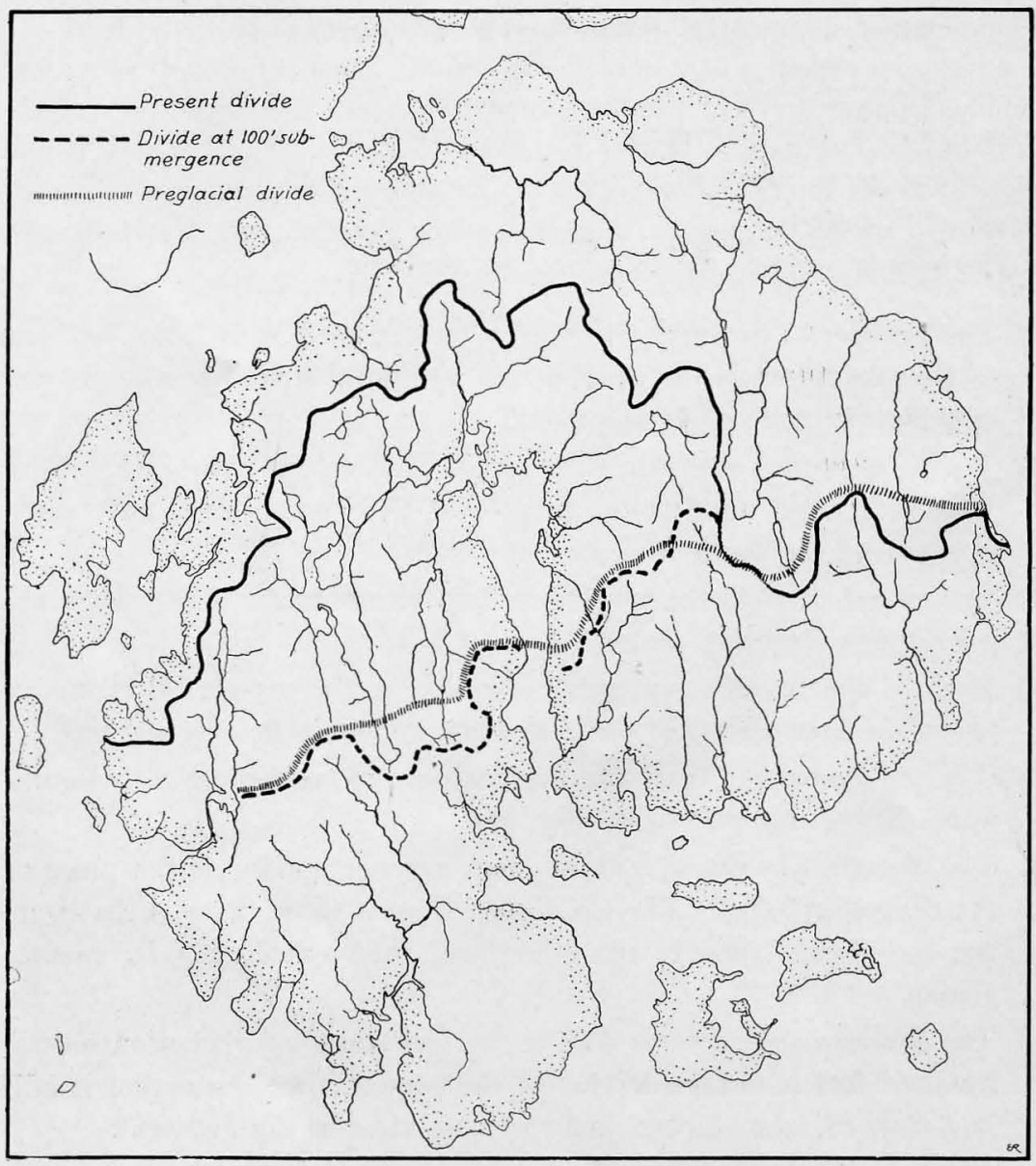

FIG. 44.-The shift of the divide on Mount Desert Island. The present divide is pushed far northward by the incision of Somes Sound. If the Island should be submerged $100^{\prime}$. Somes Sound would cut the Island in two. The divides on the resulting two islands would be much nearer the former position at the crest of Mount Desert range.

\section{The Divides}

Fig. 44 shows the pre-glacial divide as compared with the divide of the present time. The most striking fact brought out by the map is the extreme irregularity of the present divide, illustrating the disorganized state of the present drainage. Before the Ice Age the divide was where it belonged, at the crest of the Mount Desert range. The present divide is on the crest only at one point; everywhere else it lies far to the north as an indistinct line not readily perceptible in the topography. 
The northward transfer of the divide is rather accidental; it is the result of the presence of Somes Sound, which is cut straight through the mountain range and which at its northern end collects all the waters from behind the mountain. It is interesting to note that, if Somes Sound should cut the Island in two - as it nearly does - the divide on the islands so formed would be much nearer the normal position than is the present divide.

\section{THe LaKes}

Lakes are characteristic features of the young stage of drainage development, and especially so on a glaciated surface. There are about forty lakes on this relatively small island, and besides these a great many swamps, some of which represent filled-in lakes. The lakes belong to several types, and may be classified according to their origin.

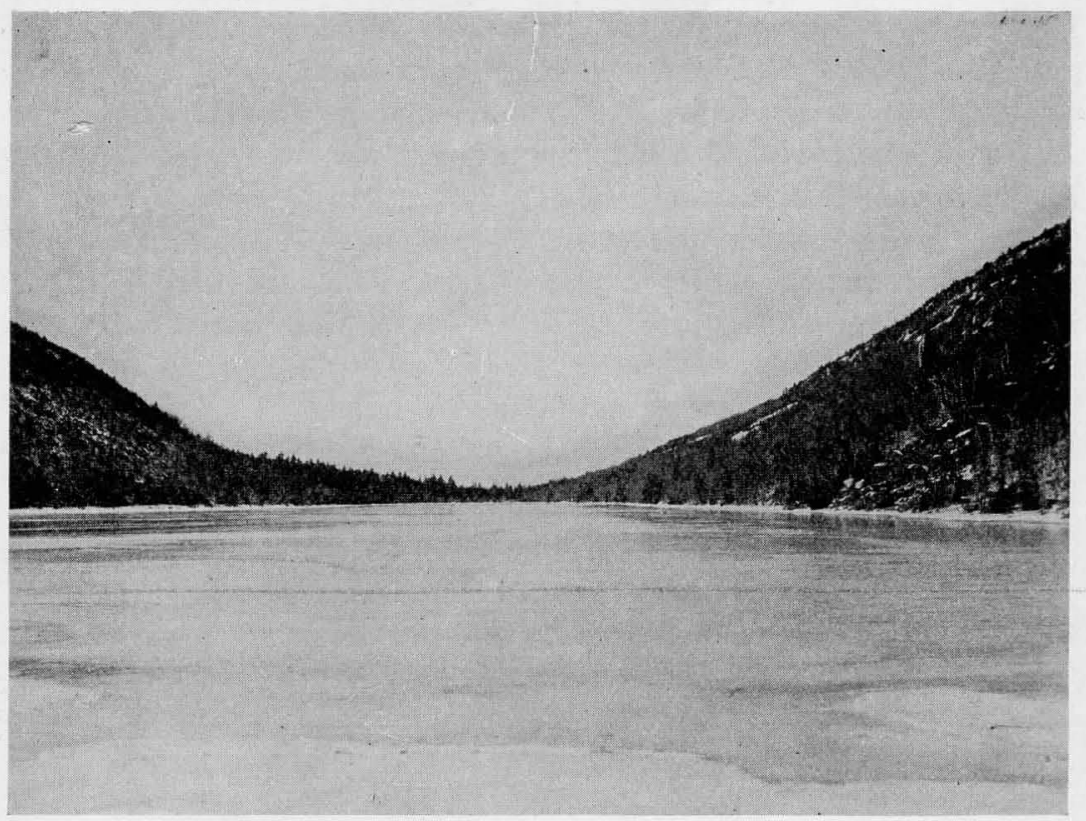

FIg. 45.-Glacial trough south of Bubble Pond.

1. LAKES OCCUPYING THE BASINS OF OVER-DEEPENED GLACIAL TROUGHS

Glacial troughs are former channels of ice streams, and like ordinary river channels they have uneven bottoms. The bottom is deepest in places where the channel passes through narrows in the mountains. As 
the ice melted away, lakes were left in the basins. To this type belong the most beautiful lakes of the Island, as the Tarn, Jordan Pond, Bubble Pond, Echo Lake, Long Pond, Seal Cove Pond and Hodgdon Pond. Somes Sound would belong to this type but for the fact that it was carved below sea level and is now filled with salt water. If the land were to rise 50 feet, it would be converted into a lake like the others.

Most of these lakes are not exactly in the middle of the mountain belt, but appear to have been pushed rather northward. This was caused in part at least by accumulation of glacial debris at the southern outlets of the glacial troughs.

2. LAKES OCCUPYING FLAT BASINS NORTH OF MOUNT DESERT RANGE FORMED BY OVER-DEEPENING OF THE ICE WHICH CONVERGED BEFORE ITS ENTRANCE INTO THE MOUNTAINS

The formation of these basins is similar to that of the previous type. More ice needs a deeper channel and carves deeper at the bottom. The difference is that, in this case, the ice was not yet closely confined by mountain walls on both sides, and so made broad and shallow depressions. Accumulation of till may add to the ponding, but these lakes are essentially rock-carved basins, and would exist even if no till were present. To this type belong Aunt Betty's Pond; the pool north of Champlain (Newport) Mountain; the northern part of Long Pond and Echo Lake can just as well be classified with this type. Eagle Lake is transitional between the first and second type.

3. LAKES AND SWAMPS FORMED IN THE SMALL TROUGHS AT THE NORTH END OF THE GRANITIC LOWLANDS

To this type belong Lake Wood, and a number of swamps. The origin of the basins is the same as in the case of the large glacial trough lakes, but they are on a smaller scale. As the continental ice sheet ascended from the northern weak rocks upon the lower rim of the granitic lowlands, it utilized the N-S valleys, and deepened them to form miniature glacial troughs the over-deepened portions of which constitute lake basins.

\section{LAKES DAMMED BY ACCUMULATION OF TILL}

This condition is chiefly responsible for the string of lakes from the northern edge of Long Pond to Somes Sound. Most of these lakes are kept at their present level by artificial dams. A number of swamps originated as lakes of this type which are now drained or filled, as those north of Somes Sound. 


\section{LAKES DERIVED BY DAMMING THE OUTLETS OF RIVERS BY WAVE-} BUILT BARS

Lakes of this type are found at Sandy Beach (Newport Cove) and at Hunter's Beach Cove, on the southern shore, as described in the previous chapter (see Fig. 42).

\section{SADDLE LAKES}

Lakes of this type occupy small depressions in the saddles of the mountains, as the Bowl, Saddle Lake on Cadillac (Green) Mountain, etc. The origin of the saddle lakes has already been discussed. They are rock basin lakes excavated in glacial spillways by the ice which passed through the saddles in a W-E direction from one glacial trough into another.

\section{\%. LAKE MAINTAINED BY BEAVER DAM}

There is one little lake which is held in place by a dam built by beavers at Duck Brook, west of Great Hill. This dam is about 150 feet long and 6 feet high, and the water held by it is of considerable volume.

There are extensive swamps in the weak-rock belt, as the North-Eastern Branch swamp in the north, and Marshall Brook swamp in the south. Actually they do not belong in the group of lakes; they are shallow bays of the sea which are now partially filled up.

\section{Post-Glacial Stream Notches}

Not only have the young streams carved deep gorges in the soft glacial debris; they have attacked locally the granite bedrock itself. Kebo Brook, between Cadillac (Green) Mountain and Flying Squadron (Dry) Mountain, and the brooks on the northern flank of Sargent Mountain, have carved into the granite post-glacial notches which in places are 50 feet deep. The big boulders in the bed of the brook are the tools with the aid of which this relatively small stream accomplished its work. The main joint-system of the granite helped to determine the remarkably straight and vertical side walls of the notches.

\section{Drainage Modifications}

Bascom (4) has described a series of stream captures on Mount Desert, and Johnson (21) has expressed some doubt as to the correctness of her interpretations. A specific case studied by the writer concerns Aunt Betty's Pond. Bascom (4-p. 128) assumes that this pond, which occupies a broad, shallow rocky basin, drained first to the north, and later was captured by Richardson's Brook, which enjoyed the advantage of a shorter and steeper descent to the sea. 
Although the map strongly suggests this explanation, the writer questions its validity. The region of Aunt Betty's Pond probably did drain to the north in pre-glacial times, but it is highly improbable that there was a lake there at that time. When the region was glaciated, the ice excavated a broad shallow basin at this place. As the ice melted, water filled the basin and overflowed to the south, as the ice presumably still blocked the pre-glacial channel to the north. The pre-glacial channel is

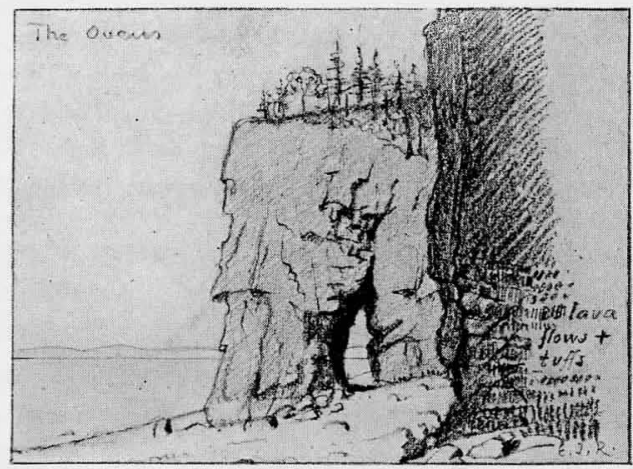

FIG. 46.-A marine arch at The Ovens.

visible north of the lake, but there is no notch in the divide which would indicate that the lake had an outlet in post-glacial time in this direction, or that capture had taken place in the manner suggested by Bascom.

\section{Future Development}

The unbalanced condition of the present drainage cannot last long. The streams will cut down their barriers and fill up the basins. The lakes and swamps will thus disappear, as many of the former lakes and swamps have already done. The streams will clean out their valleys, carrying off first the unconsolidated glacial material. Later they will cut into the bedrock, widen their valleys, and if uninterrupted in their work, will finally level down the land to a nearly flat peneplane, unless the sea waves first sweep away the Island. The granitic mountains were able to withstand peneplanation during at least one long erosion epoch, and survived as monadnocks. If a similar long erosion epoch should now follow, they would not be so well able to survive because of their dismembered condition caused by glaciation. 


\section{BIBLIOGRAPHY}

Antevs, E.

(1) 1922. The recession of the last ice sheet in New England. Amer. Geog. Soc., Research Series No. 11, 120 pp., N. Y.

(2) 1928. Late Quaternary changes of level in Maine. Amer. Jour. Sci., Ser. 5, XV, pp. 319-336.

BARRELL, T.

(3) 1920. The Piedmont terraces of the Northern Appalachians. Amer. Jour. Sci., Ser. 4, XLIX, pp. 227-258, 327-362, 407-428.

BASCOM, F.

(4) 1919. The geology of Mount Desert Island. Geog. Soc. Phila., Bull., XVII, pp. 117-130.

Bastin, E. S.

(5) 1908. Rockland quadrangle, Maine. U. S. Geol. Surv., Folio 158, 15 pp., maps.

Bastin, E. S., ANd Smith, G. O.

(6) 1907. Penobscot Bay quadrangle. U. S. Geol. Surv., Folio 149, $14 \mathrm{pp}$.

Blaney, D., And Loomis, F. B.

(7) 1916. A Pleistocene locality on Mount Desert Island, Maine. Amer. Jour. Sci., Ser. 4, XLII, pp. 399-400.

ChapmaN, H. C.

(8) 1892. Note on the geology of Mount Desert Island, Maine. Ac. Nat. Sc. Phila., Proc., 1892, p. 350 (1893).

Crosby, W. O.

(9) 1881. Geology of Frenchman's Bay, Maine. Boston Soc. Nat. Hist., Proc., XXI, pp. 109-117.

Crosby, W. O., and I. B.

(10) 1925. Keystone faults. Geol. Soc. Amer., Bull. 36, pp. 623-640.

DALE, T. N.

(11) 1907. The granites of Maine. U. S. Geol. Surv., Bull. 313, 202 pp.

(1?) 1923. The commercial granites of New England. U. S. Geol. Surv., Bull. 738, 488 pp.

DAvis, W. M.

(13) 1881. Remarks on the geology of Mount Desert Island, Maine. Boston Soc. Nat. Hist., Proc., XXI, pp. 117-118.

(14) 1894. An outline of the geology of Mount Desert (in Rand, E. S., and Redfield, J. H. : Flora of Mount Desert Island), pp. 43-71., Cambridge.

DE GEER, G.

(15) 1925. Förhistoriska Tidsbestämmingar, Ymer. XLV, pp. 1-34. (Review by Antevs, 1926, Geog. Rev., XVI, p. 170.)

(16) 1926. On the solar curve dating the Ice Age. Geogr. Annaler, VIII, pp. 253-284.

(Review in Geog. Review, XVII, 1927, pp. 503-505.) 
FaIRChiLd, H. L.

(17) 1919. Postglacial uplift of southern New England. Geol. Soc. Amer., Bull. 30, pp. 597-636.

Frazer, P.

(18) 1906. Rocks of Mount Desert Island, Maine. Geol. Soc. Amer., Bull. 16 , pp. $583-85$.

JACKSON, C. T.

(19) 1859. Crystals of green feldspar, Mount Desert, Maine. Boston Soc. Nat. Hist., Proc., VII, p. 160.

Johnson, Douglas

(20) 1919. Shore processes and shoreline development. John Wiley and Sons, N. Y.

(21) 1925. New England-Acadian shoreline. John Wiley and Sons, N. Y.

(22) 1924. La morphologie sous-marine du Golfe du Maine. Ann. de Geog., XXXIII, pp. 313-328.

JoHNSon, S. N.

(23) 1869. On the geology of the coast of Maine. Can. Nat., n. s. 4, pp. 323-324.

MoRSE, E. S.

(24) 1914. An avalanche of rocks (Mount Desert Island, Maine). Sci ence, n. s., XL, p. 241.

SHALER, N. S.

(25) 1889. The geology of the Island of Mount Desert, Maine. U. S. Sмith, G. O., ANd White, D.

(26) 1905. The geology of the. Perry Basin, Maine. U. S. Geol. Surv., Prof. Paper 35, $107 \mathrm{pp}$.

STONE, G. H.

Geol. Surv., Ann. Rpt. 8, Pt. 2, pp. 987-1061.

(27) 1899. The glacial gravels of Maine and their associated deposits. U. S. Geol. Surv., Mono. 34, 499 pp.

TrRRELL, T. B.

(28) 1910. Ice on Canadian lakes. Can. Inst. Trans., IX, pp. 13-21. WILLIS, $\mathrm{B}$.

(29) 1903. Ames Knob, North Haven, Maine. Geo. Soc. Amer., Bull. 14. pp. 201-206.

Wood, G. M.

(30) 1922. The geology of Mount Desert. Text on back of Lafayette National Park topographic sheet, U. S. Geol. Surv. 


\section{PUBLICATIONS}

OF THE

\section{NEW YORK ACADEMY OF SCIENCES}

(Lyceum of Natural History, 181\%-18\%6)

(1) The Annals (octavo series), established in 1823, contain the scientific contributions and reports of researches, together with the records of meetings of the Academy. The articles which comprise each volume are printed separately, each in its own cover, and are distributed immediately upon publication. The price of the separate articles depends upon their length and the number of illustrations, and may be ascertained upon application to the Librarian of the Academy.

(2) The Memoirs (quarto series), established in 1895, are issued at irregular intervals. It is intended that each volume shall be devoted to monographs relating to some particular department of Science. Volume $\mathrm{I}$ is devoted to Astronomical Memoirs, Volume II to Zoölogical Memoirs, etc. The price is one dollar per part.

These publications are sent free to Fellows and Active Members. The Annals are sent to Honorary and Corresponding Members desiring them.

(3) The Scientific Survey of Porto Rico and the Virgin Islands (octavo series), established 1919, gives the detailed reports of the anthropological, botanical, geological, paleontological and zoölogical surveys of these islands.

Subscriptions and inquiries concerning current and back numbers of any of the publications of the Academy should be addressed to

The Librarian

$$
\begin{gathered}
\text { New York Academy of Sciences, } \\
\text { care of }
\end{gathered}
$$

The American Museum of Natural History,

$$
\text { New York, N. Y. }
$$

